\title{
From Ligand to Complexes. Part 2. Remarks on Human Immunodeficiency Virus type 1 Integrase Inhibition by $\beta$-Diketo Acid Metal Complexes
}

\author{
Alessia Bacchi, ${ }^{\dagger}$ Mariano Biemmi, ${ }^{\ddagger}$ Mauro Carcelli, ${ }^{\dagger}$ Fabrizio Carta,${ }^{\S}$ Carlotta Compari, ${ }^{\ddagger}$ Emilia Fisicaro, ${ }^{\ddagger}$ Dominga Rogolino, \\ Mario Sechi, ${ }^{*}$, Martin Sippel, ${ }^{\prime \prime}$ Christoph A. Sotriffer,,${ }^{\prime \prime}$ Tino W. Sanchez, ${ }^{\perp}$ and Nouri Neamati ${ }^{, \perp}$ \\ Dipartimento di Chimica Generale ed Inorganica, Chimica Analitica, Chimica Fisica, Dipartimento di Scienze Farmacologiche, Biologiche e \\ Chimiche Applicate, Università di Parma, V.le Usberti 17/A, Campus Universitario, 43100 Parma, Italy, Dipartimento Farmaco Chimico \\ Tossicologico, Università di Sassari, Via Muroni 23/A, 07100 Sassari, Italy, Institut für Pharmazie und Lebensmittelchemie, Universität \\ Würzburg, Am Hubland, D-97074 Würzburg, Germany, Department of Pharmacology and Pharmaceutical Sciences, University of Southern \\ California, School of Pharmacy, 1985 Zonal Avenue, Los Angeles, California
}

Received July 18, 2008

Previously, we synthesized a series of $\beta$-diketo acid metal complexes as novel HIV-1 integrase (IN) inhibitors (J. Med. Chem. 2006, 46, 4248-4260). Herein, a further extension of this study is reported. First, detailed docking studies were performed in order to investigate the mode of binding in the active site of the free ligands and of their metal complexes. Second, a series of potentiometric measurements were conducted for two diketo acids chosen as model ligands, with $\mathrm{Mn}^{2+}$ and $\mathrm{Ca}^{2+}$, in order to outline a speciation model. Third, we designed and synthesized a new set of complexes with different stoichiometries and tested them in an in vitro assay specific for IN. Finally, we obtained the first X-ray structure of a metal complex with HIV-1 IN inhibition activity. Analysis of these results supports the hypothesis that the diketo acids could act as complexes and form complexes with the metal ions on the active site of the enzyme.

\section{Introduction}

HIV-1 integrase $\left(\mathrm{IN}^{a}\right)$ is an essential enzyme for viral replication ${ }^{1-4}$ and a validated target for the development of drugs against AIDS. ${ }^{5-7}$ It functions as a multimer ${ }^{8}$ to catalyze the insertion of viral cDNA into the host genome to form a stable provirus through two main reactions, 3 '-processing and strand transfer. ${ }^{9-11}$ Several IN inhibitors were identified through in vitro inhibition assays with recombinant $\mathrm{IN},{ }^{12-17}$ and among them the $\beta$-diketo acid (DKA) class of compounds ${ }^{18-20}$ showed the most promising results. DKAs are comprised of three structural components (Chart 1a): (a) a $\beta$-diketo moiety, (b) an aromatic or heteroaromatic portion, and (c) a carboxylic acid group, which can be replaced with a variety of bioisosteric functions. Each of these motifs lends itself to potential structure-activity explorations.

After about 15 years of study, a DKA-based derivative, MK0518 (Raltegravir, Chart 1b), ${ }^{21-23}$ has been marketed for clinical use, confirming IN as a rational retroviral drug target. Moreover, the launch of the 4-quinolone-3-carboxylic acid GS-9137 (Elviltegravir, Chart 1b) ${ }^{24,25}$ is expected soon. Although several

* To whom correspondence should be addressed: For M.S.: phone, +39 079-228-753; fax, +39 079-228-720; E-mail, mario.sechi@uniss.it. For N.N.: phone, +1 323-442-2341; fax, +1 323-442-1390; E-mail: neamati@usc.edu.

${ }^{\dagger}$ Dipartimento di Chimica Generale ed Inorganica, Chimica Analitica, Chimica Fisica, Università di Parma.

* Dipartimento di Scienze Farmacologiche, Biologiche e Chimiche Applicate, Università di Parma.

\$ Dipartimento Farmaco Chimico Tossicologico, Università di Sassari.

"Institut für Pharmazie und Lebensmittelchemie, Universität Würzburg.

${ }^{\perp}$ Department of Pharmacology and Pharmaceutical Sciences, University of Southern California, School of Pharmacy.

a Abbreviations: 3'-P, 3'-processing; 5CITEP, (2Z)-1-(5-chloro- $1 H$-indol3-yl)-3-hydroxy-3-(2H-tetrazol-5-yl)prop-2-en-1-one; AA, acetyl-acetonate; acac, acetylacetonate; ASV, avian sarcoma virus; bdp, bis-deprotonated; CSD, Cambridge Structural Database; DKA, diketo acid; dp, deprotonated; $\mathrm{H}_{2} \mathrm{~L}^{1},(2 Z)$-2-hydroxy-4-oxo-4-phenylbut-2-enoic acid; $\mathrm{H}_{2} \mathrm{~L}^{2},(2 Z)-4-[1-(4-$ fluorobenzyl)-1H-pyrrol-2-yl]-2-hydroxy-4-oxobut-2-enoic acid; $\mathrm{HC}$, hydroxyl-carboxylate; HIV-1, human immunodeficiency virus type 1; IN, integrase; mdp, monodeprotonated; ST, strand transfer.
Chart 1. (a) Classical Structure and Chemotype of DKA $\beta$-Diketo-Based Inhibitors and (b) Compounds in Clinical Trials (GS-9137) and Marketed (MK-0518)

(a)

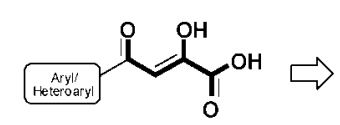

(DKA)

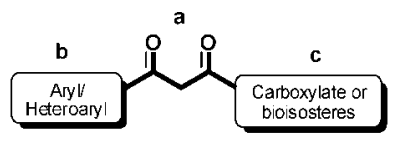

Chemotype of DKA-based compounds (b)

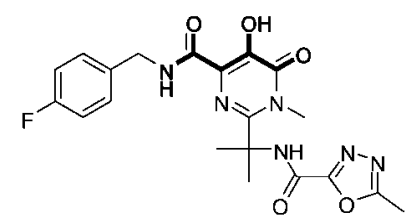

MK-0518 (Raltegravir)

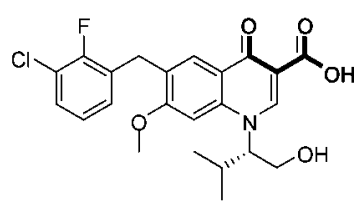

GS-9137 (JTK 303, Elviltegravir) synthetic and biological studies for DKA compounds have been reported, the mechanism by which they bind IN has not been well understood. It is believed that the DKA pharmacophoric motif could be involved in a functional sequestration of one or both divalent metal ions in the enzyme catalytic site to form a ligand- $\mathrm{M}^{2+}$-IN complex. ${ }^{26,27}$ This would subsequently block the transition state of the IN-DNA complex by competing with the target DNA substrate, acting as "interfacial inhibitor". 7,28 DKAs and DKA-like compounds therefore represent not only the most important class of IN inhibitors but they also constitute a validated prototype of metal chelating inhibitors.

We are investigating the metal complexation as a new strategy in the IN drug design. In a recent study, ${ }^{1}$ we proposed a series of DKA metal complexes as novel prototype of IN inhibitors. A series of complexes were synthesized by using the DKA ligands $\mathbf{1}$ and $\mathbf{2}$ and their methyl esters $\mathbf{3}$ and $\mathbf{4}$ (Chart 2) with a set of divalent metal ions $\left[\mathrm{Mg}^{2+}, \mathrm{Mn}^{2+}, \mathrm{Ni}^{2+}, \mathrm{Co}^{2+}, \mathrm{Cu}^{2+}\right.$, and $\left.\mathrm{Zn}^{2+}\right]$. Complexes with different stoichiometries were isolated (5a-f, 6a-f, 7a, 8a, 9a, Chart 3), fully characterized, 
Chart 2. Ligands 1-4

\section{Model ligands}

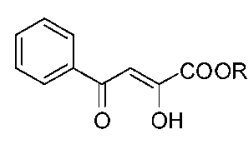

$R=H ; H_{2} L^{1}(1)$

$\mathrm{R}=\mathrm{CH}_{3} ; \mathrm{HL}^{3}(3)$

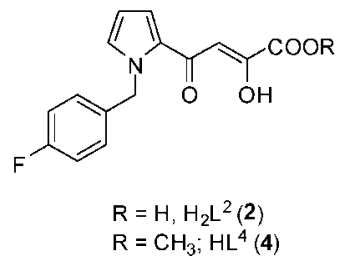

Chart 3. Structural Hypothesis for the Previously Synthesized Complexes ${ }^{1}$
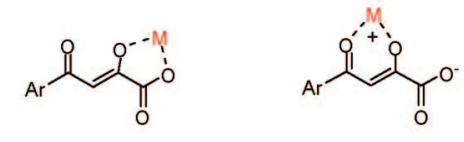

a) hydroxy-carboxylate $(\mathrm{HC})$

b) acetyl-acetonate (AA)

5,6

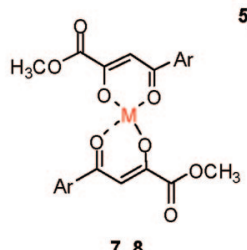

\section{$\left[\mathrm{M}_{2} \mathrm{~L}^{1}\right]\left(\mathrm{NO}_{3}\right)_{2}$}

6, 8: Ar $=(4-$ fluorobenzyl) $-1 \mathrm{H}-$ pyrrol-2-yl

9: $L^{1}=(2 Z)-2-o x i d o-4-o x o-4-p h e n y l b u t-2-e n o a t e$

$M=$ Divalent metal: $\mathbf{a}=\mathrm{Mg}(\|), \mathbf{b}=\mathrm{Mn}(\mathrm{II}), \mathbf{c}=\mathrm{Ni}(\mathrm{II}), \mathbf{d}=\mathrm{Co}(\mathrm{II}), \mathbf{e}=\mathrm{Cu}(\mathrm{II}), \mathbf{f}=\mathrm{Zn}\left({ }_{(I)}\right.$

and then tested for IN inhibition. These complexes inhibited HIV-1 IN at a high nanomolar to low micromolar range. Interestingly, they exhibited a certain "metal inhibition dependency" and, in particular, the $\mathrm{Co}^{2+}$ complexes, showed, for the phenyl series $(\mathbf{5 a}-\mathbf{f})$, the best biological profile. Encouraged by these results and in order to extend our understanding of the properties of such complexes, a series of docking studies were performed.

Initially, the free ligands 1-4 were docked in the monodeprotonated (mdp) and bis-deprotonated (bdp) forms into the active site containing one $\mathrm{Mg}^{2+}$ ion. Then 1-4 were docked as $\mathrm{Mg}^{2+}$ and $\mathrm{Co}^{2+}$ complexes into the active site, where the $\mathrm{Mg}^{2+}$ ion was removed. Finally, the complexes were docked on the protein with $\mathrm{Mg}^{2+}$ in the active site and the results from the various docking studies were compared.

To better characterize the complexation ability of the DKA system, we carried out a series of potentiometric measurements to determine the equilibrium constants between $\mathbf{1}$ and $\mathbf{2}$ with $\mathrm{Mn}^{2+}$ and $\mathrm{Ca}^{2+}$. Although $\mathrm{Mg}^{2+}$ is a more likely cofactor for integration in cells given its abundance over $\mathrm{Mn}^{2+}$, IN prefers $\mathrm{Mn}^{2+}$ in vitro. $\mathrm{Ca}^{2+}$ is a physiologically representative ion with coordination chemistry similar to $\mathrm{Mg}^{2+}$. Moreover, the set of metal complexes of $\mathbf{1}$ and $\mathbf{2}$ is increased by synthesizing their $\mathrm{Pd}^{2+}, \mathrm{Pt}^{2+}$ derivatives (11 and 13), and two new $\mathrm{Mg}^{2+}$ complexes, starting from $\mathrm{Mg}$ (acetylacetonate) $)_{2}$ (10) and $\mathrm{Mg}\left(\mathrm{NO}_{3}\right)_{2}$ (14). The new complexes were tested for anti-HIV-1 IN activity, and $\mathbf{1 4}$ demonstrated an inhibitory activity in submicromolar range. The structure of this compound was solved by single crystal X-ray crystallography. The possible mode of binding and the related mechanism of action of members of the DKA class of compounds are discussed.

\section{Molecular Modeling}

Docking of Free Ligands. The carboxylic group of $\mathbf{1}$ and $\mathbf{2}$ $\left(\mathrm{p} K_{\mathrm{a}} \sim 4\right)$ under physiological conditions is deprotonated, ${ }^{1}$ and it was modeled as a carboxylate for docking. On the contrary, the 2-enolic oxygen, with the strong intramolecular H-bond with the ketone in $\beta$-position, has been considered protonated (mdp, for 1 and 2). On the other hand, it is known that coordination increases the acidity of the ligands, so the keto-enolate form has also been evaluated; in this way, $\mathbf{1}$ and $\mathbf{2}$ result as bis-deprotonated (bdp) and $\mathbf{3}$ and $\mathbf{4}$ as deprotonated (dp). Comparison of the keto-enol (mdp) with the keto-enolate (bdp, dp) forms showed almost identical binding orientations, with slight deviations in the case of $\mathbf{1}$. Docking of the free ligands showed no complexation of the active site $\mathrm{Mg}^{2+}$ ion (Figure 1). As a reference, $\operatorname{SCITEP}^{19}$ (mdp) was docked, and a similar orientation of the keto-enol group was found. The energies and clustering data are listed in Table S1a of the Supporting Information. In docking calculations, the contributions of overall docking scores are additive, in that dimeric structures yield higher scores than monomers. Therefore, to obtain "sizeindependent" docking, a per-atom energy (i.e., the intermolecular energy divided by the number of heavy atoms and polar hydrogens) was calculated. This allowed a better comparison between monomeric ligands and dimeric complexes, without the docking score bias due to molecular sizes. Moreover, to better dissect the metal's contribution, the interaction energies of the metals were subtracted from the total energies (Table S1b of the Supporting Information).

Docking of Complexes to Protein without $\mathrm{Mg}^{2+}$ Ion in the Active Site. Docking studies were performed with complexes 5a-9a and 5d-9d. A dimeric structure was suggested for these complexes, ${ }^{1}$ but in order to better analyze their possible accommodations into the active site, the different ligand modes were independently handled in the case of 5a and $6 \mathbf{a}$ : the complexes were considered as monomers in the hydroxylcarboxylate (HC) and acetyl-acetonate (AA) forms (Chart 3). Having in mind the good biological profile of $\mathbf{5 d}$, the other $\mathrm{Co}^{2+}$ complexes 7d, 8d, and $9 d$ were also modeled, even though they were not synthesized. Docking of $\mathrm{Mg}^{2+}$ complexes (Figure 2A) showed binding orientations of $\mathbf{9 a}, \mathbf{5 a}-\mathrm{HC}$, and $\mathbf{5 a}-\mathrm{AA}$, where the $\mathrm{Mg}^{2+}$ ion was coordinated by the catalytic diad Asp64 and Asp116. Additionally, 5a-HC acted as H-bond acceptor with Thr66, as did 8a with Gln148 (Figure 2). Because of their size, complexes 6a, 7a, and 8a (Figure 2) did not fit very well in the active site. The binding modes of the complexes and of the corresponding free ligands differed in all cases. Docking of $\mathrm{Co}^{2+}$ complexes (Figure 2B) showed the same orientations for almost all the complexes (only $\mathbf{7 d}$ is slightly different), compared to their magnesium counterparts. Docking energies and clustering data are listed in Tables S2a and S2b of the Supporting Information for $\mathrm{Mg}^{2+}$ complexes and in Tables S3a and $\mathrm{S} 3 \mathrm{~b}$ of the Supporting Information for $\mathrm{Co}^{2+}$ complexes, respectively.

Docking of Complexes to Protein with $\mathrm{Mg}^{2+}$ Ion in the Active Site. Docking of 9a showed that the carboxylate group was close to the active site magnesium ion. Its own magnesium ion interacted with Glu92 and, overall, the ligand was relatively exposed in the binding site (Figure 3A). 9d showed a similar binding mode (Figure 3B). Interestingly, the $\mathbf{5 a}-\mathrm{HC}$ carboxylate group coordinated the active site $\mathrm{Mg}^{2+}$ ion while the $\mathrm{Mg}^{2+}$ ion of 5a-AA was coordinated by the catalytic residue Asp64. 


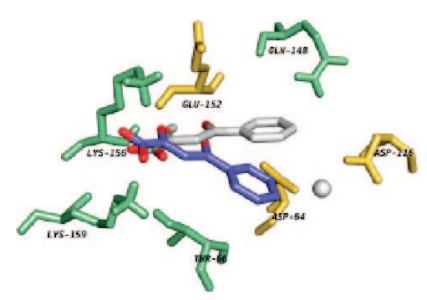

1

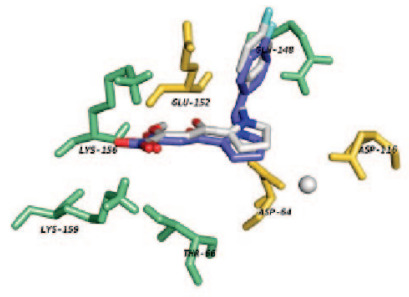

2

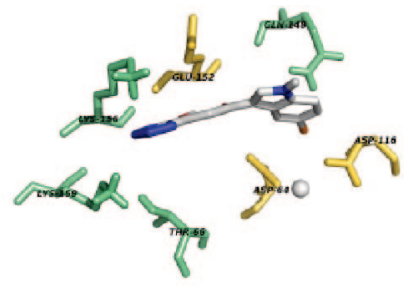

5CITEP

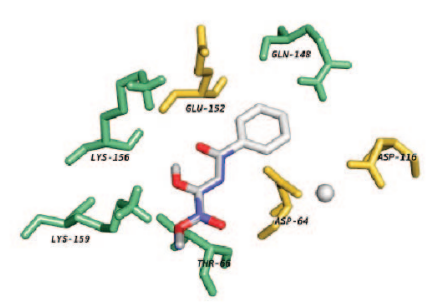

3

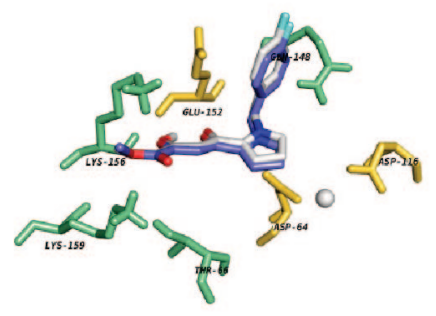

4

Figure 1. Binding modes of the top-ranked docking results for ligands $\mathbf{1}$ and $\mathbf{2}$, as monodeprotonated keto-enol (mdp, gray) and bis-deprotonated keto-enolates (bdp, blue), and for $\mathbf{3}$ and $\mathbf{4}$ in the deprotonated form; protein is shown with magnesium ion in its active site (gray sphere). The catalytic triad (Asp64, Asp116, Glu152) is shown in gold, and the residues interacting with the ligands are shown as green sticks. For reference, the docked binding mode of 5CITEP (mdp) is shown.

Moreover, the orientation of $\mathbf{5} \mathbf{d}-\mathrm{HC}$ was similar to $\mathbf{5 a}-\mathrm{HC}$, whereas the orientation of $\mathbf{5 d - A A}$ was different from 5a-AA (Figure 3). The enolate group of 7a was found in close proximity to the active site magnesium ion, and its ester functionality acted as an H-bond acceptor with Lys159. As in all the structures with two ligand molecules, the species could not be accommodated by the active site due to its large size. The replacement of magnesium with cobalt (i.e., 7d) afforded a different orientation, where both the enolate oxygen and the ester group are close to the active site magnesium ion, even though not in a good complexation geometry. Again, $6 \mathbf{a}$ and $\mathbf{6 d}$ did not show any direct interaction with the protein besides the chelation of the active site magnesium ion by the carboxylate group. In the docked orientation of $\mathbf{8 a}$ and $\mathbf{8 d}$, the pyrrole rings were exposed, whereas the fluorophenyl rings were quite buried. No direct interactions were observed. Additionally, the magnesium ion of the complex is rather close to the active site ion. Docking energies and clustering data are listed in Tables S4a and S4b of the Supporting Information.

Discussion of Docking Results. Visual inspection of the free ligand docking results showed similar orientations of the acids compared to their esters. Free ligands and their corresponding complexes in most of the cases did not have similar orientations, as expected, due to their different interaction sites (free ketoenol function vs coordinated metal ion). A first comparison of the per-atom energies of the free ligands and their respective complexes showed an energetic preference of the complex form of $\mathbf{1}$ (i.e., 9a, 5a-AA, 5a-HC) and their cobalt counterparts. Complexes $\mathbf{7 a}$ and $\mathbf{8 a}$, and their cobalt counterparts $\mathbf{7 d}$ and $\mathbf{8 d}$, had less negative energies; this was due to their size, which prevented a good accommodation by the protein and favorable interactions. Similarly, 2 was supposed to form dimeric complexes, but according to the per-atom energy, the free ligand form is preferred. In the case of $\mathbf{9 a}$ and $\mathbf{6 a}$, the question arose whether it was possible for an active site to incorporate three 2-fold positive ions. However, a closer look on the binding energies revealed that the energetic contributions of the com- plexes' metal ions were unrealistically high; therefore, the results of the docking study without $\mathrm{Mg}^{2+}$ in the active site were not optimal.

In contrast, the docking study with $\mathrm{Mg}^{2+}$ in the active site yielded reasonable energetics. This was due to the occupation by the magnesium ion of the interaction site near the catalytic residues Asp64 and Asp116, which was responsible for unrealistically high energetic contributions of the complexes' metal ions when docked to the magnesium-free binding site (Table $\mathrm{S} 5 \mathrm{~b}$ of the Supporting Information). Comparing the per-atom energies of complexes with the free ligands (see Table S6b of the Supporting Information), the complexes perform better in case of 5a-HC and 5a-AA. As a reference, the protonated form of the free ligands should instead be considered (see above). It is interesting to note that, in the obtained binding modes of 5aAA and 7a and of their cobalt counterparts, the positioning of the metal ions resembled the respective structural features of ASV integrase (pdb: 1VSH), which is considered a homologous model for the IN active site with two $\mathrm{Mg}^{2+}$. According to the obtained docked energies, all cobalt complexes are stronger binders than the corresponding magnesium complexes, in agreement with the activity data.

\section{Chemistry}

Potentiometric Measurement and Calculations. Potentiometric studies on the solution behavior of $\mathbf{1}$ and $\mathbf{2}$ were carried out with $\mathrm{Ca}^{2+}$ and $\mathrm{Mn}^{2+}$ (Figure 4 and Table 1). To avoid solubility problems, all the titrations were performed in methanol/ water solution $(9: 1 \mathrm{v} / \mathrm{v})$. The best fit of the experimental titration curves was obtained by using the set of species reported in Table 1. The species found in solution with $\mathrm{Mn}^{2+}\left[\mathrm{H}_{2} \mathrm{~L}\right.$ (diprotic ligand), $\mathrm{ML}_{2}{ }^{2-}, \mathrm{M}_{2} \mathrm{~L}^{2+}, \mathrm{M}_{2} \mathrm{~L}_{2}$, and $\left.\mathrm{M}_{2} \mathrm{~L}_{2}(\mathrm{OH})^{-}\right]$are the same as in the case of $\mathrm{Mg}^{2+},{ }^{1}$ but the formation constants are greater and show a higher stability than the former complexes. $\mathrm{ML}_{2}{ }^{2-}$ and $\mathrm{M}_{2} \mathrm{~L}_{2}(\mathrm{OH})^{-}$were not found for $\mathrm{Ca}^{2+}$; in fact, in alkaline solution, only $\mathrm{Ca}_{2} \mathrm{~L}_{2}$ is present. As shown by the distribution diagrams in Figure $4 a-d$, at physiological $p H$, the species $M_{2} L_{2}$ is the most abundant one for both ligands and metal ions. $\mathrm{M}_{2} \mathrm{~L}^{2+}$ 
A)

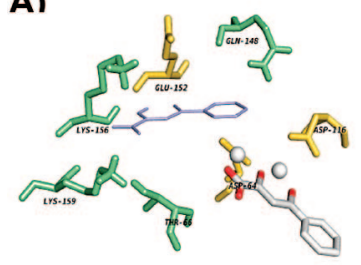

$9 a$

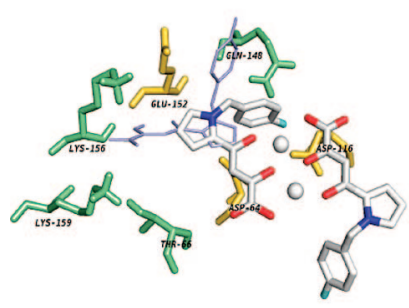

$6 a$

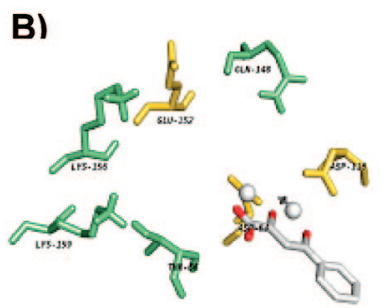

9d

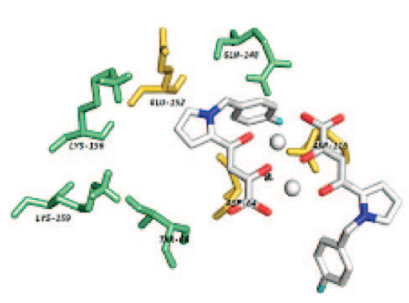

6d

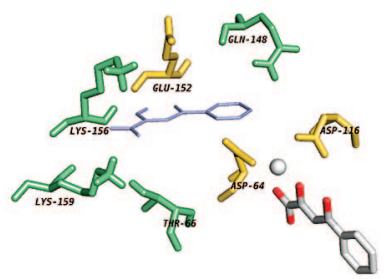

5a $(\mathrm{HC})$

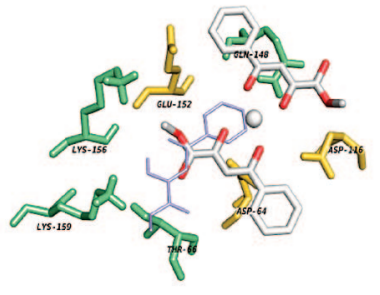

$7 a$

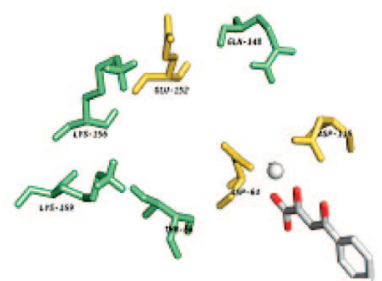

$5 d(\mathrm{HC})$

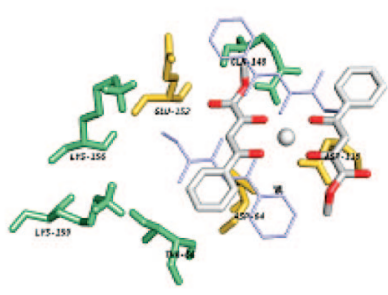

7d

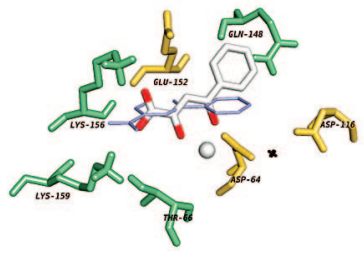

5a (AA)

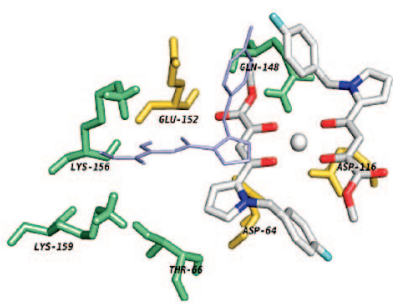

$8 \mathbf{a}$

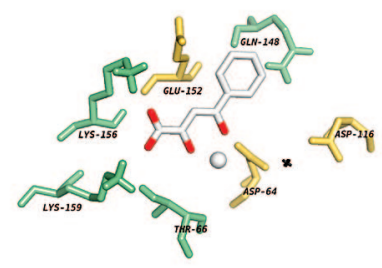

5d (AA)

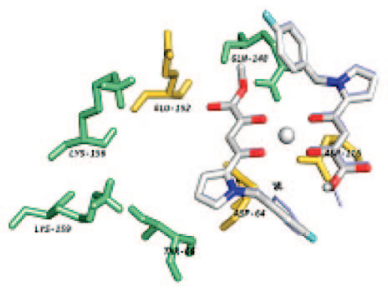

8d

Figure 2. Binding modes of the top-ranked docking results for $\mathrm{Mg}^{2+}$ complexes (A) and $\mathrm{Co}^{2+}$ complexes (B); protein with no magnesium ion in its active site. For reference, the respective free ligands are shown as light-blue lines, and the position of the active site magnesium ion is marked with a cross.

is formed at more acidic $\mathrm{pH}$ (see complex 9). The formation constants of the monomeric species, ML, and of the dimeric one, $\mathrm{M}_{2} \mathrm{~L}_{2}$, cannot be refined together, probably because of their high mathematical correlation. As already noted ${ }^{1}$ by means of potentiometry alone, we cannot completely exclude the presence in solution of the monomeric species, because the model with ML instead of $\mathrm{M}_{2} \mathrm{~L}_{2}$ is only slightly unfavorable. The reason of our choice is due, in addition to the slightly better statistical values, to the fact that $\mathrm{M}_{2} \mathrm{~L}_{2}$ was also supported by spectroscopic and molecular modeling data. In the case of $\mathrm{Mn}^{2+}, \mathrm{ML}_{2}{ }^{2-}$ has been also introduced, formed by coordination of the 2-enolate and carboxylate oxygen to the metal ion (Figure 4c,d), while species with the monoprotonated ligand, $\mathrm{HL}^{-}$, were rejected by the software. $\mathrm{ML}(\mathrm{OH})^{-}$, or its dimer $\mathrm{M}_{2} \mathrm{~L}_{2}(\mathrm{OH})_{2}{ }^{-}$, slightly improve the statistical parameters of the fitting, but they are eventually formed, if formed at all, at very alkaline $\mathrm{pH}$ (Figure 4a,b). Computed and experimental titration curves fit perfectly for the experiments conducted in 1:2 and 1:4 M:L ratios for all the examined metal:ligand couples. The slightly worse fit for the 1:1 M:L ratio can be explained by a partial hydrolysis of the cation, not avoided by the low quantity of ligand in solution. In fact, in this case the titration points at intermediate $\mathrm{pH}$ reach the equilibrium very slowly.

Synthesis and Characterization of the Complexes 10-14. The platinum(II) complexes of the DKA $1\left(\mathrm{H}_{2} \mathrm{~L}^{1}\right)$ and $2\left(\mathrm{H}_{2} \mathrm{~L}^{2}\right)$, as well as the palladium(II) and magnesium acetylacetonate complexes with $\mathbf{1}$, have been synthesized and fully characterized (Scheme 1). $\mathbf{1 0}$ has been isolated by reacting $\mathbf{1}$ with $\operatorname{Mg}(\mathrm{acac})_{2}$, with the aim to avoid the dimeric structure of $5 \mathbf{a}$ and 6a by using a coligand that "blocks" two coordinating positions around the metal. In 10, the ligand becomes completely deprotonated, as can be inferred by the ${ }^{1} \mathrm{H}$ NMR (no $\mathrm{OH}$ resonance), and by the IR spectra (the $\mathrm{OH}$ absorption is no longer visible, and the carboxylic $\mathrm{C}=\mathrm{O}$ stretching mode at 1735 $\mathrm{cm}^{-1}$ in the free ligand is replaced by two bands at 1521 and $1392 \mathrm{~cm}^{-1}$, imputable to the $v(\mathrm{O}-\mathrm{C}-\mathrm{O})$ asymmetric and 


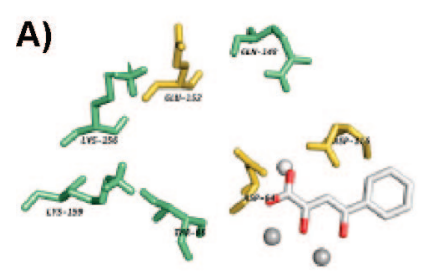

9a

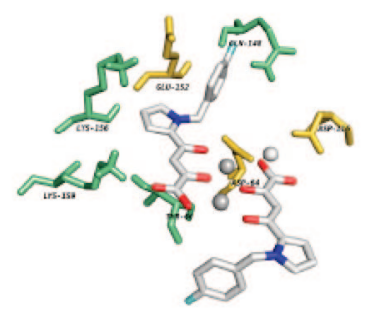

$6 a$

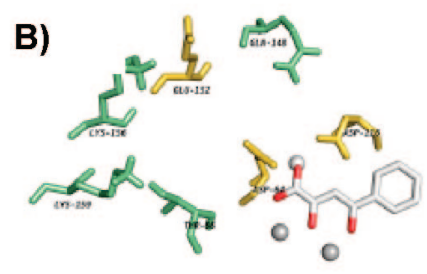

$9 d$

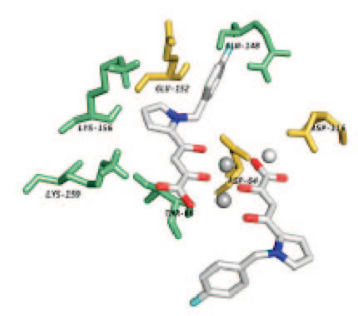

$6 d$

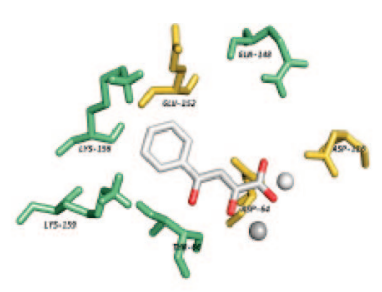

5 a $(\mathrm{HC})$

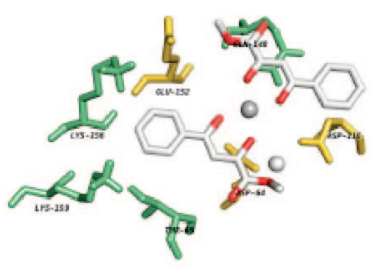

$7 a$

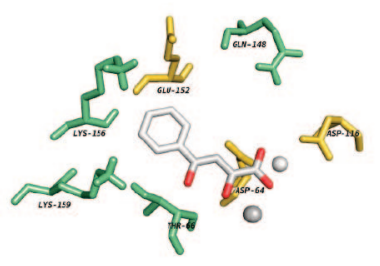

5d $(\mathrm{HC})$

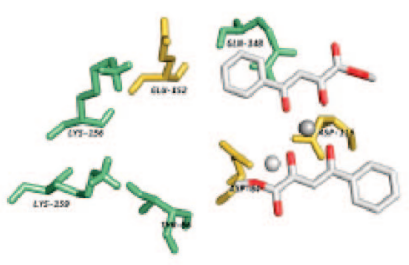

$7 d$

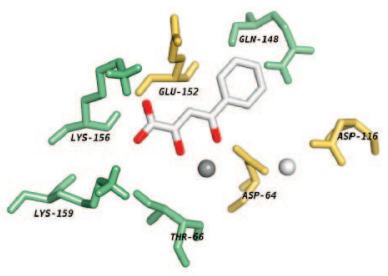

5a (AA)

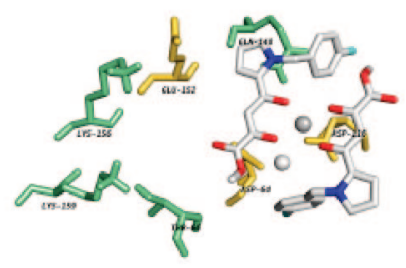

8a

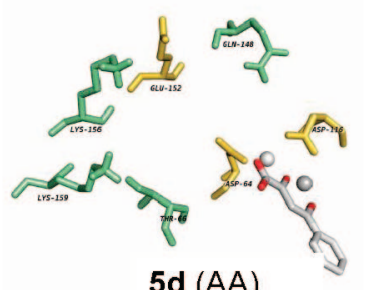

5d (AA)

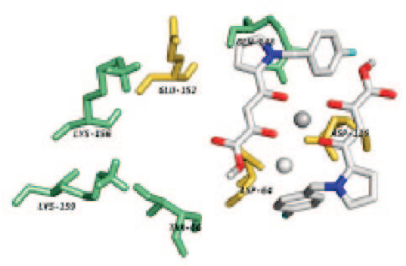

8d

Figure 3. Binding modes of the top-ranked docking results for $\mathrm{Mg}^{2+}$ complexes (A) and $\mathrm{Co}^{2+}$ complexes (B); protein with magnesium ion in its active site (shown as white sphere).

Table 1. Logarithms of Protonation and $\mathrm{Mg}(\mathrm{II})$ Complex Formation Constants $\left(\beta p q r=\left[\mathrm{M}_{p} \mathrm{~L}_{q} \mathrm{H}_{r}\right] /[\mathrm{M}]^{p}[\mathrm{~L}]^{q}[\mathrm{H}]^{r}\right)$ in Methanol/Water $=9: 1 \mathrm{v} / \mathrm{v}, I=0.1$ $\mathrm{M} \mathrm{KCl}$ at $25^{\circ} \mathrm{C}$ for the Ligands Under Study with $\mathrm{Ca}(\mathrm{II}), \mathrm{Mn}(\mathrm{II})$, and $\mathrm{Mg}(\mathrm{II})^{a}$

\begin{tabular}{|c|c|c|c|c|c|c|c|c|c|c|}
\hline & & \multirow[b]{2}{*}{$p$} & \multirow[b]{2}{*}{$q$} & \multirow[b]{2}{*}{$r$} & \multicolumn{2}{|c|}{$\mathrm{M}=\mathrm{Ca}(\mathrm{II})$} & \multicolumn{2}{|c|}{$\mathrm{M}=\mathrm{Mn}(\mathrm{II})$} & \multicolumn{2}{|c|}{$\mathrm{M}=\mathrm{Mg}(\mathrm{II})^{b}$} \\
\hline & & & & & $\mathrm{H}_{2} \mathrm{~L}^{1}$ & $\mathrm{H}_{2} \mathrm{~L}^{2}$ & $\mathrm{H}_{2} \mathrm{~L}^{1}$ & $\mathrm{H}_{2} \mathrm{~L}^{2}$ & $\mathrm{H}_{2} \mathrm{~L}^{1}$ & $\mathrm{H}_{2} \mathrm{~L}^{2}$ \\
\hline $\mathrm{M}+2 \mathrm{~L} \rightleftharpoons \mathrm{ML}_{2}$ & & 1 & 2 & 0 & & & $11.58(0.29)$ & $13.41(0.35)$ & $8.81(0.30)$ & $12.45(0.26)$ \\
\hline $2 \mathrm{M}+\mathrm{L} \rightleftharpoons \mathrm{M}_{2} \mathrm{~L}$ & & 2 & 1 & 0 & $10.42(0.06)$ & $11.24(0.11)$ & $10.12(0.26)$ & $12.16(0.15)$ & $9.43(0.17)$ & $10.46(0.16)$ \\
\hline \multicolumn{2}{|c|}{$2 \mathrm{M}+2 \mathrm{~L}+\mathrm{OH} \rightleftharpoons \mathrm{M}_{2} \mathrm{~L}_{2}(\mathrm{OH})$} & 2 & 2 & -1 & & & $8.46(016)$ & $11.62(0.17)$ & $3.89(0.18)$ & $7.80(0.10)$ \\
\hline & $p$ & & $q$ & & \multicolumn{3}{|c|}{$\mathrm{H}_{2} \mathrm{~L}^{1_{b}}$} & \multicolumn{3}{|c|}{$\mathrm{H}_{2} \mathrm{~L}^{2} b$} \\
\hline
\end{tabular}

${ }^{a}$ Standard deviations are given in parentheses. Charges are omitted for simplicity. ${ }^{b}$ Data from ref 1.

symmetric stretching vibrations). Moreover, the ${ }^{1} \mathrm{H}$ NMR spectrum clearly indicates a 1:2 ligand:acac ratio, as also confirmed by elemental analysis. Because the spectra are similar between $\mathbf{1 0}$ and the previously reported magnesium complex 5a, where the ligand coordinates two metal ions through the acetyl, hydroxyl, and carboxylic moieties, we can reasonably assume a similar coordinating behavior for the ligand in $\mathbf{1 0}$. In
10, the coordinating positions around the magnesium ions are completed by two acetylacetonate ligands (Figure 5).

Also in the palladium complex 11, the ligand is bisdeprotonated, leading to a stoichiometry of type ML. The complete deprotonation of the ligand is confirmed by the spectroscopy data: in the ${ }^{1} \mathrm{H}$ NMR spectrum, the acidic protons are absent, while in the IR spectrum, the $\mathrm{OH}$ and the carboxylic 

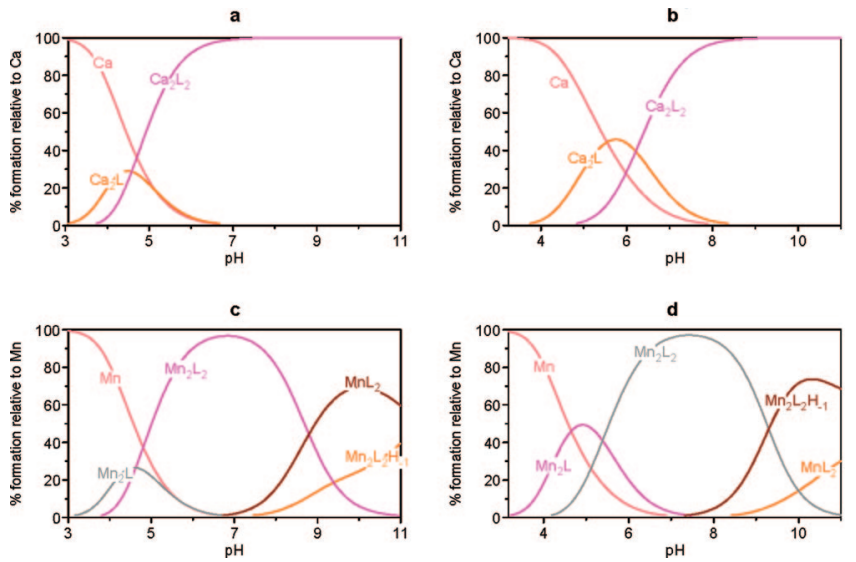

Figure 4. Distribution diagrams for the systems under investigation at $\mathrm{L}: \mathrm{M}=2: 1$ (the concentration of the ligand is $4 \mathrm{mM}$ ): (a) $\mathrm{L}=\mathrm{H}_{2} \mathrm{~L}^{1}$, $\mathrm{M}=\mathrm{Ca}$ (II), (b) $\mathrm{L}=\mathrm{H}_{2} \mathrm{~L}^{2}, \mathrm{M}=\mathrm{Ca}(\mathrm{II})$, (c) $\mathrm{L}=\mathrm{H}_{2} \mathrm{~L}^{1}, \mathrm{M}=\mathrm{Mn}$ (II), and (d) $\mathrm{L}=\mathrm{H}_{2} \mathrm{~L}^{2}, \mathrm{M}=\mathrm{Mn}(\mathrm{II})$.

Scheme 1. Preparation of Complexes 10-14

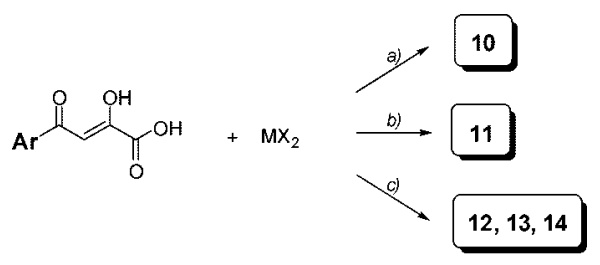

10, 11, 12: Ar $=$ Phenyl (Phe)

13, 14: $\mathrm{Ar}=($ 4-fluorobenzyl) $-1 \mathrm{H}$-pyrrol-2-yl $(\mathrm{FBP})$

$\mathrm{MX}_{2}=$ metal sait

${ }^{a}$ Reagents and conditions: (a) methanol, $\mathrm{Mg}(\mathrm{acac})_{2}$ solution in methanol, rt, $2 \mathrm{~h}$; (b) methanol, $\mathrm{Pd}\left(\mathrm{CH}_{3} \mathrm{COO}\right)_{2}$ solution in methanol, rt, $1 \mathrm{~h}$; (c) 12 and 13: methanol, $0.1 \mathrm{M} \mathrm{KOH}$ until pH 7, $\mathrm{K}_{2} \mathrm{PtCl}_{4}$ in water, rt, 2-4 h; 14: $0.1 \mathrm{M} \mathrm{NaOH}$ until $\mathrm{pH} 7, \mathrm{Mg}\left(\mathrm{NO}_{3}\right)_{2}$ in water, $\mathrm{rt}, 2 \mathrm{~h}$.

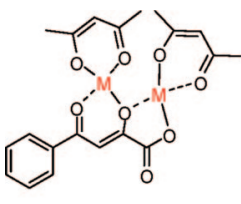

10

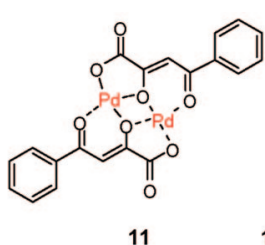

11

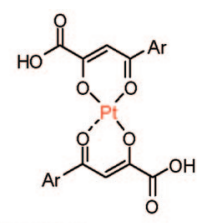
12: $\mathrm{Ar}=$ phenyl
13: $\mathrm{Ar}=$ (4-Fluorobenzyl)-1 H-pyrrol-2-yl
Figure 5. Structural hypothesis for the complexes 10-13.

$\mathrm{C}=\mathrm{O}$ stretching band disappear. The presence of water molecules is indicated by a broad absorption at $3450 \mathrm{~cm}^{-1}$, and it is confirmed by elemental analysis. Unfortunately, the compound is not stable in open air or in solution and was kept under nitrogen. The diketo acid moiety can give rise to both a hydroxyl-carboxylate and an acetyl-acetonate type of coordination (Chart 3). We suppose that the spectral analogies with the other complexes lead to a dimeric structure also for $\mathbf{1 1}$, with the acetyl, the hydroxyl, and the carboxylate groups of the ligand involved in the coordination (Figure 5). A different situation is observed for the platinum complex 12. An attempt to prepare $\mathrm{PtL}^{1}$ has instead led to the bis-chelate $\mathrm{Pt}\left(\mathrm{HL}^{1}\right)_{2}$, where two monodeprotonated ligands coordinate to the metal center. The yield of the reaction was optimized by reacting the metal salt and the ligand in the appropriate 1:2 stoichiometric ratio (procedure B in the Experimental Section). In the ${ }^{1} \mathrm{H}$ NMR spectrum, the resonance of one acidic proton was around 14 ppm, while in the IR spectrum, the stretching band of the carboxylic moiety was at $1625 \mathrm{~cm}^{-1}$. The shift vs the free ligand $\left(1735 \mathrm{~cm}^{-1}\right)$ is therefore less than in the palladium analogue $\left(1557 \mathrm{~cm}^{-1}\right)$. A similar shift has been previously observed in

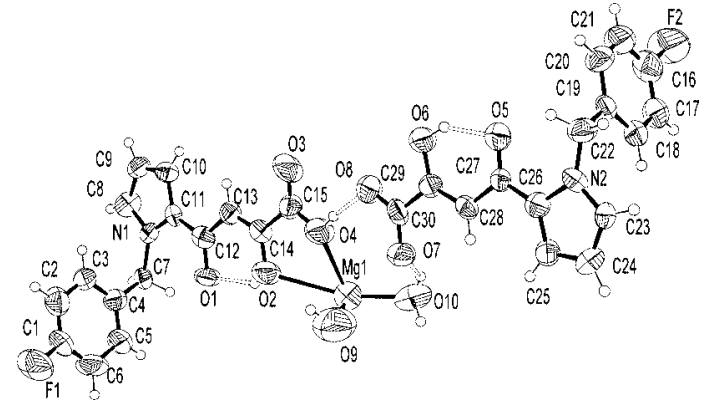

Figure 6. Perspective view and labeling of the asymmetric unit of $\left[\mathrm{Mg}\left(\mathrm{HL}^{2}\right)\left(\mathrm{H}_{2} \mathrm{~L}^{2}\right)(\mathrm{OH})\left(\mathrm{H}_{2} \mathrm{O}\right)\right]$, thermal ellipsoids at the 50\% level. Relevant hydrogen bonds are dashed.

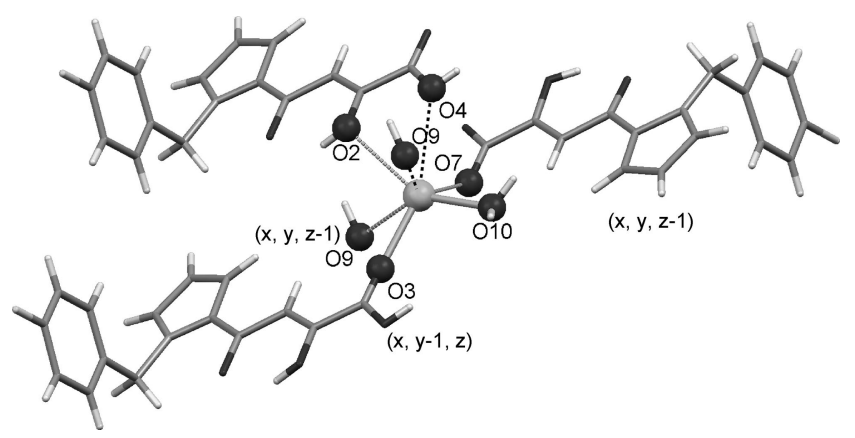

Figure 7. $(5+2)$ Coordination of magnesium in $\mathbf{1 4}$ and symmetry operations required to build the coordination environment.

the complex $\left(1 R, 2 R\right.$-cyclohexanediamine- $\left.N, N^{\prime}\right)[2$-hydroxy-4oxo-2-pentenoato]platinum(II) ${ }^{29}$ and in a copper(II) complex of $\mathrm{H}_{2} \mathrm{~L}^{1}{ }^{30}$ In both cases, it was determined by $\mathrm{X}$-ray diffraction analysis that the ligand coordinated in the acetyl acetonate form. It is therefore plausible to assume an acetylacetonate coordination in $\mathbf{1 2}$ and also in the other platinum complex 13, whose spectroscopic characterization was analogous. These complexes were stable both in solution and in the solid state. Finally, compound $\mathbf{1 4}$ was isolated in an attempt to obtain a complex as $\left[\mathrm{Mg}_{2} \mathrm{~L}^{1}\right]\left(\mathrm{NO}_{3}\right)_{2}(\mathbf{9 a})$ by reacting $\mathrm{H}_{2} \mathrm{~L}^{2}$ with $\mathrm{Mg}\left(\mathrm{NO}_{3}\right)_{2}$ at $\mathrm{pH}$ 7. It was unambiguously characterized as $\left[\mathrm{Mg}\left(\mathrm{HL}^{2}\right)\left(\mathrm{H}_{2} \mathrm{~L}^{2}\right)(\mathrm{OH})\left(\mathrm{H}_{2} \mathrm{O}\right)\right]$ by obtaining single crystals suitable for $\mathrm{X}$-ray diffraction analysis.

Crystal Structure of the Magnesium Complex 14. In 14 complexation occurred by heptacoordination of $\mathrm{a} \mathrm{Mg}^{2+}$ cation to one carboxylic carbonyl of a neutral $\mathrm{H}_{2} \mathrm{~L}^{2}$ ligand (O3), a carboxylate oxygen $(\mathrm{O} 7)$ of a deprotonated $\left(\mathrm{HL}^{2}\right)^{-}$, a water molecule (O10), two $\mathrm{OH}^{-}$anions shared between two cations (O9), and two $-\mathrm{OH}$ groups belonging to a second $\mathrm{H}_{2} \mathrm{~L}^{2}$ molecule (O2 and $\mathrm{O} 4)$, with a final stoichiometry of $\left[\mathrm{Mg}\left(\mathrm{HL}^{2}\right)\left(\mathrm{H}_{2} \mathrm{~L}^{2}\right)(\mathrm{OH})\left(\mathrm{H}_{2} \mathrm{O}\right)\right]$ (Figure 6 and Figure 7). The cation coordination was quite irregular, and the $\mathrm{Mg}-\mathrm{O}$ distances, ranging between 2.22 and $2.88 \AA$, were rather long compared, for example, to that of $\left[\mathrm{Mg}\left(\mathrm{H}_{2} \mathrm{O}\right)_{6}\right]^{2+}$ or RCOO-Mg (average $\mathrm{Mg}-\mathrm{O}$ in the $\mathrm{CSD}=2.07 \AA$ for both cases). Together with the $\mathrm{O}-\mathrm{Mg}-\mathrm{O}$ angles point to a $5+2$ distorted coordination (Table 2). The shortest distances $(<2.45 \AA)$ in the magnesium surroundings referred to the coordination of two carboxylate groups and a water molecule that formed a tripodal system around the cation. Two longer contacts (between 2.55 and 2.70 $\AA$ ) joined the cation to the enolic $\mathrm{OH}$ of $\mathrm{H}_{2} \mathrm{~L}^{2}$ and to an $\mathrm{OH}^{-}$ anion, while the remaining two longest interactions (between 2.84 and $2.90 \AA$ ) connected the cation to a second $\mathrm{OH}^{-}$and to the carboxylic $\mathrm{OH}$ adjacent to the enolic group in $\mathrm{H}_{2} \mathrm{~L}^{2}$, forming a weak chelate system (Figure 7). Thus, bidimensional arrays 
Table 2. Bond Lengths $(\AA)$ and Angles (deg) of Magnesium Coordination in $\mathbf{1 4}^{a}$

\begin{tabular}{|c|c|c|c|c|c|}
\hline bond & length, $\AA$ & bond & angles, deg & bond & angles, deg \\
\hline $\mathrm{Mg} 1-\mathrm{O} 10$ & $2.22(2)^{b}$ & $\mathrm{O} 10-\mathrm{Mg} 1-\mathrm{O} 3(\mathrm{i})$ & $97.3(6)$ & $\mathrm{O} 4-\mathrm{Mg} 1-\mathrm{O} 9$ & $64.9(6)$ \\
\hline $\mathrm{Mg} 1-\mathrm{O} 3(\mathrm{i})$ & $2.28(1)$ & $\mathrm{O} 10-\mathrm{Mg} 1-\mathrm{O} 7(\mathrm{ii})$ & $87.0(6)$ & $\mathrm{O} 4-\mathrm{Mg} 1-\mathrm{O} 2$ & $55.4(4)$ \\
\hline Mg1-O7(ii) & $2.43(1)$ & $\mathrm{O} 3(\mathrm{i})-\mathrm{Mg} 1-\mathrm{O} 7(\mathrm{ii})$ & $126.9(8)$ & $\mathrm{O} 4-\mathrm{Mg} 1-\mathrm{O} 3(\mathrm{i})$ & $151.7(7)$ \\
\hline $\mathrm{Mg} 1-\mathrm{O} 2$ & $2.67(1)$ & $\mathrm{O} 3(\mathrm{i})-\mathrm{Mg} 1-\mathrm{O} 9$ & $91.0(6)$ & $\mathrm{O} 4-\mathrm{Mg} 1-\mathrm{O} 9$ (ii) & $117.9(5)$ \\
\hline $\mathrm{Mg} 1-\mathrm{O} 4$ & $2.84(1)$ & $\mathrm{O} 7(\mathrm{ii})-\mathrm{Mg} 1-\mathrm{O} 9$ & $140.3(6)$ & O9(ii)-Mg1-O10 & 141(1) \\
\hline \multirow[t]{3}{*}{ Mg1-O9(ii) } & $2.88(3)$ & $\mathrm{O} 10-\mathrm{Mg} 1-\mathrm{O} 2$ & $144.4(9)$ & O9(ii)-Mg1-O9 & 138.7(9) \\
\hline & & $\mathrm{O} 3(\mathrm{i})-\mathrm{Mg} 1-\mathrm{O} 2$ & 107.7(5) & O9(ii) $-\mathrm{Mg} 1-\mathrm{O} 2$ & $73.05(6)$ \\
\hline & & $\mathrm{O} 4-\mathrm{Mg} 1-\mathrm{O} 10$ & $91.1(7)$ & & \\
\hline
\end{tabular}

\footnotetext{
${ }^{a}$ Symmetry transformations used to generate equivalent atoms: (i) $x, y-1, z$; (ii) $x, y, z-1 .{ }^{b}$ In parentheses are the s.u. values.
}

Table 3. Crystal Data and Structure Refinement for Complex 14

\begin{tabular}{|c|c|c|}
\hline empirical formula & $\mathrm{C}_{30} \mathrm{H}_{26} \mathrm{~F}_{2} \mathrm{Mg} \mathrm{N}_{2} \mathrm{O}_{10}$ & \\
\hline formula weight & 636.84 & \\
\hline temperature, $\mathrm{K}$ & 293(2) & \\
\hline wavelength, $\AA$ & 1.54178 & \\
\hline crystal system & triclinic & \\
\hline space group & $P 1$ & \\
\hline \multirow{3}{*}{ unit cell dimensions $(\AA, \mathrm{deg})$} & $a=21.064(4)$ & $\alpha=81.887(7)$ \\
\hline & $b=6.7136(5)$ & $\beta=92.748(9)$ \\
\hline & $c=5.1000(4)$ & $\gamma=89.856(9)$ \\
\hline volume, $\AA^{3}$ & $713.16(16)$ & \\
\hline$Z$ & 1 & \\
\hline density (calculated), $\mathrm{Mg} / \mathrm{m}^{3}$ & 1.483 & \\
\hline absorption coefficient & $1.221 \mathrm{~mm}^{-1}$ & \\
\hline$F(000)$ & 330 & \\
\hline$\theta$ range for data collection, deg & $4.20-70.04$ & \\
\hline reflections collected & 2702 & \\
\hline independent reflections & 2702 & \\
\hline refinement method & full-matrix least-squares on $F^{2}$ & \\
\hline data/restraints/parameters & $2702 / 11 / 417$ & \\
\hline goodness-of-fit on $F^{2}$ & 0.961 & \\
\hline final $R$ indices $[I>2 \sigma(I)]$ & $R 1=0.0864, w R 2=0.2224$ & \\
\hline$R$ indices (all data) & $R 1=0.1486, w R 2=0.2980$ & \\
\hline largest $\Delta F$ maximum $/$ minimum, $\mathrm{e} \cdot \AA^{-3}$ & $1.050 /-0.346$ & \\
\hline
\end{tabular}

of magnesium cations were bridged by $\mathrm{OH}^{-}$anions along $c$ and by $\mathrm{H}_{2} \mathrm{~L}^{2}$ along $b$, while water molecules and deprotonated $\left(\mathrm{HL}^{2}\right)^{-}$were coordinated to only one cation (Figure 8, left). Double layers of ligand molecules held together by the hydroxymagnesium core were formed, and the fluorinated aromatic groups were exposed on the outer surface of these layers. This peculiar framework clearly favored the transition between species with varying degrees of hydration and deprotonation because the terminal carboxylate was preorganized to coordinate to a vicinal $\mathrm{Mg}^{2+}$, and the pending water might have shifted to bridge pairs of cations by mirroring the $\mathrm{OH}^{-}$and symmetrizing the structure. A network of intra- and intermolecular hydrogen bonds stabilized this arrangement. The ketoenolic moieties formed intramolecular hydrogen bonds $[\mathrm{O} 2 \cdots \mathrm{O} 1=2.51(1) \AA$, $\mathrm{O} 2-\mathrm{H} \cdots \mathrm{O} 1=140.2(8)^{\circ} ; \mathrm{O} 6 \cdots \mathrm{O} 5=2.55(1) \AA$, O6 $-\mathrm{H} \cdots \mathrm{O} 5$ $\left.=144.1(8)^{\circ}\right]$, the water bridges two consecutive anionic carboxylates along $b[\mathrm{O} 10 \cdots \mathrm{O} 7=3.17(3) \AA$, $\mathrm{O} 10-\mathrm{H} 1 \cdots \mathrm{O} 7$ $=140(9)^{\circ} ; \mathrm{O} 10 \cdots \mathrm{O} 8(x, y-1, z)=2.88(2) \AA, \mathrm{O} 10-\mathrm{H} 2 \cdots \mathrm{O} 8(x$, $\left.y-1, z)=133(12)^{\circ}\right]$, and the hydroxyl pointed to the ketoenolic system of a $\mathrm{H}_{2} \mathrm{~L}^{2}$ displaced along $c[\mathrm{O} 9 \cdots \mathrm{O} 2(x, y, z+1)=$
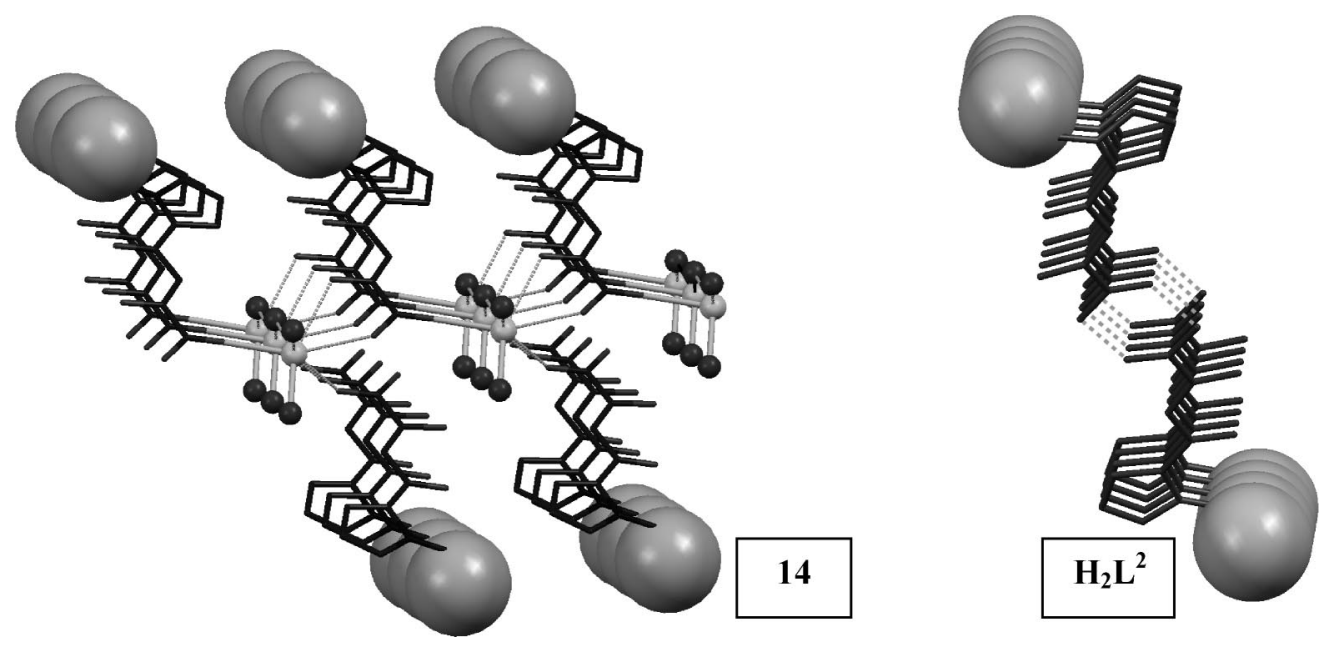

Figure 8. Crystal organization of $\mathrm{H}_{2} \mathrm{~L}^{2}$, $\left(\mathrm{HL}^{2}\right)^{-}, \mathrm{H}_{2} \mathrm{O}$, and $\mathrm{OH}^{-}$around $\mathrm{Mg}^{2+}$ in $\mathbf{1 4}$ (left) and crystal packing of $\mathrm{H}_{2} \mathrm{~L}^{2}$ alone ${ }^{1}$ (right). Fluorobenzene substituents are represented as large balls for clarity. Hydrogens omitted. Water molecules and bridging $\mathrm{OH}^{-}$anions are indicated as dark balls around $\mathrm{Mg}^{2+}$ cations represented as light balls. 
Table 4. Inhibition of HIV-1 IN Catalytic Activities of Ligands and Complexes

\begin{tabular}{llcccr}
\hline compd & ${ }^{a} \mathrm{M}$ & ${ }^{b} \mathrm{M}: \mathrm{L}$ & $\begin{array}{c}3^{\prime} \text {-processing } \\
\mathrm{IC}_{50}(\mu \mathrm{M})\end{array}$ & $\begin{array}{c}\text { strand transfer } \\
\mathrm{IC}_{50}(\mu \mathrm{M})\end{array}$ & ${ }^{c} \mathrm{SI}$ \\
\hline $\mathbf{1}^{\boldsymbol{d}}$ & & & $>333$ & $69 \pm 4$ & $>5$ \\
$\mathbf{2}^{\boldsymbol{d}}$ & & & $15 \pm 2$ & $0.54 \pm 0.08$ & 28 \\
$\mathbf{5 a}^{\boldsymbol{d}}$ & $\mathrm{Mg}^{2+}$ & $1: 1$ & $>333$ & $44 \pm 3$ & $>8$ \\
$\mathbf{5 d}^{\boldsymbol{d}}$ & $\mathrm{Co}^{2+}$ & $1: 1$ & $50 \pm 9$ & $5 \pm 3$ & 10 \\
$\mathbf{6 a}^{\boldsymbol{d}}$ & $\mathrm{Mg}^{2+}$ & $1: 1$ & $6 \pm 1$ & $0.26 \pm 0.04$ & 23 \\
$\mathbf{6 d}^{\boldsymbol{d}}$ & $\mathrm{Co}^{2+}$ & $1: 1$ & $9 \pm 4$ & $0.72 \pm 0.33$ & 12 \\
$\mathbf{9}^{\boldsymbol{d}}$ & $\mathrm{Mg}^{2+}$ & $2: 1$ & $>333$ & $88 \pm 5$ & $>4$ \\
$\mathbf{1 0}$ & $\mathrm{Mg}^{2+}$ & $2: 1$ & $>333$ & $143 \pm 15$ & $>2$ \\
$\mathbf{1 1}$ & $\mathrm{Pd}^{2+}$ & $1: 1$ & $73 \pm 6$ & $20 \pm 2$ & 3.5 \\
$\mathbf{1 2}$ & $\mathrm{Pt}^{2+}$ & $1: 2$ & $>100$ & $35 \pm 3$ & $>2.8$ \\
$\mathbf{1 3}$ & $\mathrm{Pt}^{2+}$ & $1: 2$ & $>33$ & $2.4 \pm 2$ & $>13$ \\
$\mathbf{1 4}$ & $\mathrm{Mg}^{2+}$ & $1: 2$ & $6 \pm 1$ & $0.37 \pm 0.23$ & 16 \\
\hline$a$ & & & & & \\
\hline
\end{tabular}

${ }^{a} \mathrm{M}=$ metal ion. ${ }^{b} \mathrm{M}: \mathrm{L}=$ metal:ligand ratio. ${ }^{c}$ SI: selectivity index ${ }^{d}$ Data from ref 1 .

3.31(3) $\AA$, O9- $\left.\mathrm{H} \cdots \mathrm{O} 2(x, y, z+1)=131(11)^{\circ}\right]$. Most importantly, the neutral and the anionic carboxylate facing each other between two cations were strongly linked together $[\mathrm{O} 4 \cdots \mathrm{O} 8$ $=2.46(2) \AA$, O4 $\left.-\mathrm{H} \cdots \mathrm{O} 8=170.5(9)^{\circ}\right]$.

The remarkable irregularity of the solid state molecular association in $\mathbf{1 4}$ was caused by the coexistence of species with different protonation states $\mathrm{HL}^{2-}, \mathrm{H}_{2} \mathrm{~L}^{2}, \mathrm{OH}^{-}$, and $\mathrm{H}_{2} \mathrm{O}$, and it was reflected by crystallization in the least symmetric space group $P 1$, although no chiral centers are present in the single molecular components. The role of the magnesium cation in the solid state organization of $\mathbf{1 4}$ may be grasped by comparing its crystal structure with that of the free neutral ligand ${ }^{1} \mathrm{H}_{2} \mathrm{~L}^{2}$ (Figure 8 , right). The latter pairs of $\mathrm{H}_{2} \mathrm{~L}^{2}$ were strongly associated with two hydrogen bonds forming the carboxylic acid dimer pattern, whereas the introduction of the magnesium cation destroyed the dimers by generating catemers where one hydrogen bond between carboxylic groups was preserved and the other was replaced by a $\mathrm{Mg}(\mathrm{OH})\left(\mathrm{H}_{2} \mathrm{O}\right)^{+}$bridging moiety.

\section{Biology}

Inhibition of HIV-1 IN. Complexes 10-14 were designed to explore the chemical features required for the activity of this class of compounds. In particular, complex $\mathbf{1 0}$ was prepared to evaluate the activity of a "hybrid" complex where the organic scaffold is constituted of a simple DKA (1) from one side and an inactive acetylacetone from the other side. $\mathbf{1 1}$ followed the trend of the complexes described in the previous series (5) but with $\mathrm{Pd}^{2+}$ as metal ion. Complexes 12 and 13 were structurally different for both the new metal ion $\left(\mathrm{Pt}^{2+}\right)$ and their stoichiometry ( $M: L=1: 2)$. Then, we also obtained an interesting new complex (14) with an original structural rearrangement. All of them were tested for their ability to inhibit IN catalytic activities, 3 -processing and strand transfer, in in vitro assays employing purified enzyme. The results, reported in comparison with those of the previously synthesized free ligands (1 and $\mathbf{2}$ ) and complexes (5a,d, 6a,d, and 9a), are summarized in Table 4.

With an $\mathrm{IC}_{50}$ value of $143 \pm 15 \mu \mathrm{M}, \mathbf{1 0}$ was 2- and 3-fold less active than $\mathbf{1}$ and $\mathbf{5 a}\left(\mathrm{IC}_{50 \mathrm{~s}}=69 \pm 4\right.$ and $44 \pm 3 \mu \mathrm{M}$ for strand transfer for $\mathbf{1}$ and $\mathbf{5 a}$, respectively). This indicated that the nature of the ligands significantly influenced the inhibition potency. $\mathrm{Pd}^{2+}$ complex 11, when tested against IN, exhibited the same "metal inhibition dependency", already observed in the compounds of the series $\mathbf{5}$. Compound $\mathbf{1 1}$ showed an $\mathrm{IC}_{50}$ value of $20 \pm 2$ and $73 \pm 6 \mu \mathrm{M}$ for strand transfer and $3^{\prime}$ processing, respectively (for a representative gel, see Figure 9), and was 2-fold more potent for strand transfer than the respective $\mathrm{Mg}^{2+}$ derivative $\left(\mathrm{IC}_{50}=44 \pm 3 \mu \mathrm{M}\right)$. This confirmed the notion

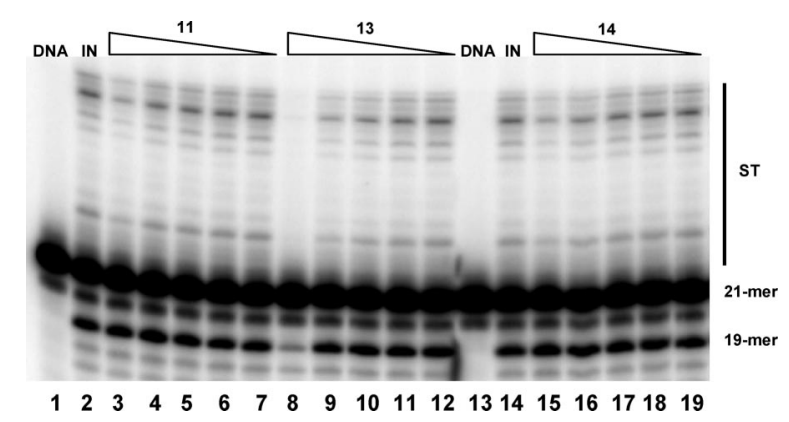

Figure 9. Representative gel showing inhibition of purified IN by selected compounds 11, 13, and 14. Lanes 1 and 12: DNA alone; lanes 2 and 14: IN and DNA with no drug; other lines: IN, DNA, and selected drug concentrations as indicated above each lane. All inhibitor concentrations decrease from $100 \mu \mathrm{M} \rightarrow 33 \mu \mathrm{M} \rightarrow 11 \mu \mathrm{M} \rightarrow 3.7 \mu \mathrm{M}$ $\rightarrow 1.4 \mu \mathrm{M}$.

that the nature of the metal ions also influences the activity. While the $\mathrm{Pt}^{2+}$ complex 12 resulted in a 2 -fold increase in potency $\left(\mathrm{IC}_{50}=35 \pm 3 \mu \mathrm{M}\right.$ for strand transfer) compared to the ligand 1, complex 13 showed a slight decrease in potency $\left(\mathrm{IC}_{50}=2.4 \pm 2\right.$ for strand transfer and 3'-processing, Figure 7 ), when compared with 2 . However, these complexes showed a range of potency similar to the others obtained in a 2:2 M:ligand stoichiometry, such as $\mathbf{5}$ and 6. Interestingly, the complex $14\left(\mathrm{IC}_{50}=0.37 \pm 0.23\right.$ and $6 \pm 1 \mu \mathrm{M}$ for strand transfer and 3'-processing, respectively, Figure 7) was the most potent compound, with 2 -fold greater potency than its free ligand $2\left(\mathrm{IC}_{50}=0.54 \pm 0.08\right.$ and $15 \pm 2 \mu \mathrm{M}$ for strand transfer and 3 '-processing, respectively). Analysis of these results suggested that only active ligands (e.g., DKA) were needed on the organic scaffold to retain the intrinsic potency of this class of compounds. Moreover, it was interesting to observe that not only complexes with 2:2 metal:ligand ratio, but also 1:2 complexes demonstrate a favorable structural combination, as revealed by their potency.

\section{How Do Inhibitors Bind in the Active Site?}

Although the exact mechanism of action of IN inhibitors has not been elucidated, it is believed that most IN specific inhibitors interfere with metal ions in the IN active site. Therefore, metal chelation at the catalytic core could be exploited in the design of new inhibitors with better selectivity toward IN ${ }^{27}$ Obviously, major insights will be obtained when a crystal structure of the enzyme complexed with its DNA substrate becomes available. There are several unanswered questions about the exact role, the type, and number of metal ions within the enzyme active site. It is generally accepted that $\mathrm{Mg}^{2+}$ is a more likely cofactor for integration in cells given its one million-fold abundance over $\mathrm{Mn}^{2+}$, even though the activity of purified enzyme is more robust with $\mathrm{Mn}^{2+}$ than $\mathrm{Mg}^{2+}$.

In designing selective ligands interacting with such metal ions, structural considerations have to be invoked together with the electronic nature of the ligand donor centers. In particular, $\mathrm{Mg}^{2+}$ prefers an octahedral coordination, but steric constraints of polydentate ligands could prevent coordination. $\mathrm{Mn}^{2+}$ forms mainly high-spin octahedral complexes, and it has a more flexible coordination sphere than the smaller $\mathrm{Mg}^{2+}$. Although $\mathrm{Mn}^{2+}$ can functionally replace $\mathrm{Mg}^{2+}$ in its catalytic and structural role, the different electronic and geometrical features of the two ions can explain the discrepancies observed using different enzyme assay conditions, as well as the differences in activity for inhibitors bearing bioisosteric pharmacophoric fragments. Therefore, it is important to investigate the com- 
plexing ability of the diketo acid pharmacophore. In our study, it is particularly interesting to note that several species $\left[\mathrm{ML}_{2}{ }^{2-}\right.$, $\mathrm{M}_{2} \mathrm{~L}^{2+}, \mathrm{M}_{2} \mathrm{~L}_{2}$, and $\mathrm{M}_{2} \mathrm{~L}_{2}(\mathrm{OH})^{-}$] were found in solution for $\mathrm{Mn}^{2+}$ by potentiometric titration studies (Figure 4, Table 1). These species were the same for $\mathrm{Mg}^{2+1}$, but with higher stability. When the behavior of DKAs in the presence of $\mathrm{Mg}^{2+}$ was investigated, the species $\mathrm{M}_{2} \mathrm{~L}_{2}$ are predominant at physiological $\mathrm{pH}$ for both $\mathbf{1}$ and 2 . The high affinity for the $\mathrm{Mn}^{2+}$ shown by DKAs could in part explain why many inhibitors that were identified by high-throughput screening technology using $\mathrm{Mn}^{2+}$ as a cofactor were inactive in the presence of $\mathrm{Mg}^{2+}$. Also, $\mathrm{M}_{2} \mathrm{~L}_{2}$ species were predominant at physiological $\mathrm{pH}$ for $\mathrm{Ca}^{2+}$ (II), with a formation constant comparable to that of the $\mathrm{Mn}^{2+}$ (II) complex. However, the presence of a small amount $(\sim 10 \%)$ of $\mathrm{ML}_{2}$ was observed at physiological $\mathrm{pH}$ by titration of $\mathrm{H}_{2} \mathrm{~L}^{2}$. The experiment involving calcium ions was carried out to both expand the evaluation of the complexation ability and to study the affinity of DKAs toward other physiological representative metal ions.

Another important topic to investigate is at which step of the catalytic sequence the IN inhibitors act. This is important for the design of novel inhibitors, as free ligands or complexes can interfere with one or two metals either directly in a single step or in a sequential manner. In fact, some DKAs show certain inhibitory activity against the 3 '-processing step but at a higher concentration than strand transfer. Therefore, they can bind before $3^{\prime}$-processing (for example to one $\mathrm{Mg}^{2+}$ ), and then they can interfere with the other metal when it is kept in the active site. Otherwise, they can independently and not sequentially bind to both steps more or less strongly, depending upon the availability of one or both metal ions. The selectivity displayed by DKAs for the strand transfer reaction could be therefore explained by the fact that inhibitors need both metal ions to bind strongly and that the second metal binds only in the presence of a DNA substrate. In fact, only one $\mathrm{Mg}^{2+}$ has been detected in the active site in crystallographic studies, ${ }^{11,31}$ but the presence of the viral DNA might be critical for the second metal binding. This is a more realistic representation of the physiological conditions. The absence of this second metal ion in the crystal structures led to the hypothesis that the metal ion is bound to the substrate (i.e., DNA). Considering DKAs as competitive inhibitors of this substrate, the hypothesis of DKAs acting as metal complexes is in good agreement with this idea.

Because we demonstrated the formation of complexes in solution by DKAs, our studies strongly suggested the hypothesis that these compounds can immediately form complexes in in vitro enzymatic studies and in vivo in the presence of divalent metal ions in the intracellular space. Following this reasoning, the DKAs and their metal complexes may act as interfacial inhibitors both by involving an unique mechanism and by interfering with IN and acceptor (viral) DNA, and in this way they may block the strand transfer reaction, as previously suggested. Such interference with the enzyme could be due to the following mechanisms: (a) the complex binds "as is" to IN, it keeps its metals and occupies the binding site as a single "static" entity, or (b) upon binding to IN, a dynamic exchange of the metal ions occurs, and the ligand releases its complexed metals and forms instead a complex with the metal ions in the binding site. Molecular modeling results seem to support the hypothesis that DKAs could act themselves as complexes, or by forming a stable complex with the metal ions on the active site. In fact, the complexes showed a better docking energy than the free ligand and a more favorable accommodation in the active site, especially when considered in the monomeric form.
In the absence of a cocrystal structure, the previously described "two-metal binding" model inhibition mechanism could be reasonably extended to the DKA family.

\section{Conclusions}

Both structural studies on HIV-1 IN inhibitors and the biology of metal cofactors have confirmed the important role of metal ions in the inhibition process and that the metal ion binding function is a critically important factor in the development of IN inhibitors. In this study, we extended the investigation of the complexing ability of DKAs in solution by considering other representative divalent metal ions, and we performed a molecular recognition study of the binding mode of free ligands and complexes by means of a molecular modeling docking approach. Furthermore, we obtained new insights from the biological investigation of a new set of synthesized complexes. Although we do not have a clear explanation concerning the possible interaction of these inhibitors at the molecular level, analysis of all results seems to support the hypothesis that members of the DKA class could act themselves as complexes or at least form a stable complex with metal ions on the IN active site.

Of course, further experiments are needed to confirm this assumption. For example, from the molecular dynamics studies with a second metal ion in the active site, it seems that the third catalytic residue, Glu152, which in the crystal structure points away from the active site, tilts toward the second metal ion and the active site. ${ }^{32}$ This might also happen upon binding of an inhibitor-metal complex, and it therefore plays an important role in terms of protein-ligand interaction energies. Besides, the biological evaluation of a greater number of complexes, with DKA or DKA-based compounds as ligands, would be useful for a careful SAR rationalization. Work is in progress in this direction to obtain more information for clarifying the complex's behavior. Finally, our studies suggest that the metal chelation strategy can not only help in designing second generation IN inhibitors and the understanding of IN mechanism, but it can also be extended to other enzymes of therapeutic importance.

\section{Experimental Section}

Chemistry. All reagents of commercial quality were used without further purification. Proton NMR spectra were recorded at $27^{\circ} \mathrm{C}$ on a Bruker 300 FT spectrophotometer by using TMS as internal standard, while IR spectra were obtained with a Nicolet 5PCFTIR spectrophotometer in the $4000-400 \mathrm{~cm}^{-1}$ range, using $\mathrm{KBr}$ disks or, where indicated, the reflectance mode on the powder. Elemental analyses were performed by using a Carlo Erba model EA 1108 apparatus.

The ligands $\mathrm{H}_{2} \mathrm{~L}^{1}$ (1) and $\mathrm{H}_{2} \mathrm{~L}^{2}$ (2) were prepared as previously described. ${ }^{1}$

Preparation of the Complexes 10-14. $\operatorname{Mg}_{2}\left(\mathrm{~L}^{1}\right)(\operatorname{acac})_{2}$. $2 \mathbf{H}_{2} \mathbf{O}$ (10). $\mathrm{H}_{2} \mathrm{~L}^{1}(0.1 \mathrm{~g}, 0.5 \mathrm{mmol})$ was dissolved in $15 \mathrm{~mL}$ of methanol and added dropwise to a methanolic solution of $\mathrm{Mg}(\mathrm{acac})_{2}$ $(1 \mathrm{mmol}$; acac $=$ acetylacetonate $)$. The solution was light yellow and the final $\mathrm{pH}$ neutral. The reaction mixture was stirred at room temperature for $2 \mathrm{~h}$ and concentrated under vacuum to obtain a white powder; yield: $75 \% ; \mathrm{mp}>280{ }^{\circ} \mathrm{C}$. IR $\left(\mathrm{cm}^{-1}\right): v_{\mathrm{C}=\mathrm{O}}=1597$, 1521, 1392. ${ }^{1} \mathrm{H}$ NMR (DMSO-d $\left.d_{6}\right): \delta 7.95$ (d, br, $\left.2 \mathrm{H}, \mathrm{H}_{\text {arom }}\right), 7.50$ (m, 3H, $\mathrm{H}_{\text {arom }}$ ), 7.04 (s, br, $1 \mathrm{H}, \mathrm{CH}_{\text {enolic }}$ ), 5.08 (s, br, $2 \mathrm{H}, \mathrm{CH}_{\text {acac }}$ ), 1.75 (s, $\left.12 \mathrm{H}, \mathrm{CH}_{3}\right)$. Anal. $\left(\mathrm{C}_{20} \mathrm{H}_{20} \mathrm{O}_{8} \mathrm{Mg}_{2} \cdot 2 \mathrm{H}_{2} \mathrm{O}\right) \mathrm{C}, \mathrm{H}$.

$\mathbf{P d L}^{1} \cdot \mathrm{H}_{2} \mathrm{O}(\mathbf{1 1}) . \mathrm{H}_{2} \mathrm{~L}^{1}(0.1 \mathrm{~g})$ was dissolved in dry methanol under nitrogen and added to an equimolar solution of $\mathrm{Pd}\left(\mathrm{CH}_{3} \mathrm{COO}\right)_{2}$ in methanol $(15 \mathrm{~mL})$. After $1 \mathrm{~h}$ at room temperature, a brown precipitate formed, which was filtered off, washed with methanol, and dried under vacuum. The product is unstable in solution and in open air and so it was kept under nitrogen; yield: $82 \%$. IR $\left(\mathrm{cm}^{-1}\right): v_{\mathrm{OH}}=3450 ; v_{\mathrm{C}=\mathrm{O}}=1557,1348 .{ }^{1} \mathrm{H}$ NMR (DMSO- $\left.d_{6}\right): \delta$ 
$7.88\left(\mathrm{~d}, 2 \mathrm{H}, \mathrm{H}_{\text {arom }}\right), 7.62\left(\mathrm{t}, 1 \mathrm{H}, \mathrm{H}_{\text {arom }}\right), 7.50\left(\mathrm{t}, 2 \mathrm{H}, \mathrm{H}_{\text {arom }}\right), 4.60(\mathrm{~s}$, $\left.1 \mathrm{H}, \mathrm{CH}_{\text {enolic }}\right)$. Anal. $\left(\mathrm{C}_{10} \mathrm{H}_{6} \mathrm{O}_{4} \mathrm{Pd} \cdot \mathrm{H}_{2} \mathrm{O}\right) \mathrm{C}, \mathrm{H}$.

$\operatorname{Pt}\left(\mathbf{H L}^{\mathbf{1}}\right)_{2}$ (12). Procedure A: $\mathrm{H}_{2} \mathrm{~L}^{1}(0.5 \mathrm{mmol})$ was dissolved in $10 \mathrm{~mL}$ of methanol and the $\mathrm{pH}$ adjusted to 7 by using $\mathrm{KOH}(1 \mathrm{M})$. The solution of the ligand was added dropwise to an aqueous solution of $\mathrm{K}_{2} \mathrm{PtCl}_{4}(0.5 \mathrm{mmol})$. The reaction mixture was stirred at room temperature for $2 \mathrm{~h}$ and monitored by TLC $\left(\mathrm{CHCl}_{3}: \mathrm{CH}_{3} \mathrm{OH}\right.$ $7: 3$ ). The solution was deep orange. The solvent was eliminated under vacuum and the residue retrieved with methanol and dichloromethane. A solid was separated (salt in excess). The yellow filtrate was concentrated and passed over celite to eliminate residual $\mathrm{KCl}$; finally a yellow powder was isolated, washed with diethyl ether, and dried under vacuum; $m p=190-192{ }^{\circ} \mathrm{C}$ (dec). IR $\left(\mathrm{cm}^{-1}\right): v_{\mathrm{C}=\mathrm{O}}=1625,1383 .{ }^{1} \mathrm{H}$ NMR $\left(\mathrm{DMSO}-d_{6}\right): \delta 14.51(\mathrm{~s}, \mathrm{br}$, $1 \mathrm{H}, \mathrm{OH}), 8.03$ (d, 2H, $\left.\mathrm{H}_{\text {arom }}\right), 7.67$ (t, $\left.1 \mathrm{H}, \mathrm{H}_{\text {arom }}\right), 7.56$ (t, $2 \mathrm{H}$, $\mathrm{CH}_{\text {arom }}$ ), 6.99 (s, $1 \mathrm{H}$, br, $\mathrm{H}_{\text {enolic }}$ ). Anal. $\left(\mathrm{C}_{20} \mathrm{H}_{14} \mathrm{O}_{8} \mathrm{Pt}\right) \mathrm{C}, \mathrm{H}$. Procedure $\mathrm{B}: \mathrm{H}_{2} \mathrm{~L}^{1}(0.5 \mathrm{mmol})$ was dissolved in $10 \mathrm{~mL}$ of methanol and the $\mathrm{pH}$ adjusted to 7 by using $\mathrm{KOH}(1 \mathrm{M})$. The solution of the ligand was added dropwise to an aqueous solution of $\mathrm{K}_{2} \mathrm{PtCl}_{4}(0.25 \mathrm{mmol})$. The reaction mixture was stirred at room temperature for $4 \mathrm{~h}$. The solution was bright yellow. The solvent was removed under vacuum, and a yellow powder was isolated, washed with diethyl ether, and dried under vacuum.

$\operatorname{Pt}\left(\mathbf{H L}^{2}\right)_{2}$ (13). The same as $\operatorname{Pt}\left(\mathrm{HL}^{1}\right)_{2}$, procedure $\mathrm{B}$, by using $\mathrm{H}_{2} \mathrm{~L}^{2}$; yellow powder; mp $>250{ }^{\circ} \mathrm{C}$. IR $\left(\mathrm{cm}^{-1}\right): v_{\mathrm{C}=\mathrm{O}}=1633$, 1394. ${ }^{1} \mathrm{H}$ NMR (DMSO- $\left.d_{6}\right): \delta 13.84$ (s, br, $\left.1 \mathrm{H}, \mathrm{OH}\right), 7.18(\mathrm{~d}, 2 \mathrm{H}$, $\mathrm{H}_{\text {arom }}$ ), 7.01 (d, 2H, $\left.\mathrm{H}_{\text {arom }}\right), 6.73$ (s, $\left.1 \mathrm{H}, \mathrm{CH}_{\text {enolic }}\right), 6.38$ (s, 1H, $\left.\mathrm{H}_{\text {imid }}\right)$, $6.19\left(\mathrm{~s}, 1 \mathrm{H}, \mathrm{H}_{\text {imid }}\right), 5.90\left(\mathrm{~s}, 1 \mathrm{H}, \mathrm{H}_{\text {imid }}\right), 5.64\left(\mathrm{~s}, 2 \mathrm{H}, \mathrm{CH}_{2}\right)$. Anal. $\left(\mathrm{C}_{30} \mathrm{H}_{22} \mathrm{~F}_{2} \mathrm{~N}_{2} \mathrm{O}_{8} \mathrm{Pt}\right) \mathrm{C}, \mathrm{H}, \mathrm{N}$.

$\mathbf{M g}\left(\mathbf{H L}^{\mathbf{2}}\right)\left(\mathbf{H}_{2} \mathrm{~L}^{\mathbf{2}}\right)(\mathbf{O H})\left(\mathbf{H}_{2} \mathrm{O}\right) \cdot \mathbf{2} \mathbf{H}_{2} \mathrm{O}(\mathbf{1 4}) . \mathrm{H}_{2} \mathrm{~L}^{2}(0.5 \mathrm{mmol})$ was dissolved in $15 \mathrm{~mL}$ of methanol and water (1:1) and the $\mathrm{pH}$ adjusted to 7 by using a $0.1 \mathrm{M}$ aqueous solution of $\mathrm{NaOH}$. The ligand was then added dropwise to an aqueous solution of $\mathrm{Mg}\left(\mathrm{NO}_{3}\right)_{2}(1 \mathrm{mmol})$. The reaction mixture was stirred at room temperature for $2 \mathrm{~h}$ and then the solvent was removed under vacuum. The residue was retrieved with methanol, filtered, and concentrated until a highly hygroscopic white powder was isolated. IR (reflectance mode, $\left.\mathrm{cm}^{-1}\right): v_{\mathrm{OH}}=3401, v_{\mathrm{C}=\mathrm{O}}=1584 .{ }^{1} \mathrm{H}$ NMR (DMSO- $\left.d_{6}\right)$ : d7.32-6.90 (m, 12H, $\left.\mathrm{H}_{\text {arom }}+\mathrm{CH}_{\text {imid }}\right), 6.72\left(\mathrm{~s}, \mathrm{br}, 2 \mathrm{H}, \mathrm{CH}_{\text {imid }}\right), 6.16$ (s, br, $2 \mathrm{H}, \mathrm{CH}_{\text {imid }}$ ), 5.95 (s, br, $\left.1 \mathrm{H}, \mathrm{OH}\right), 5.66$ (s, br, 4H, $\mathrm{CH}_{2}$ ), 5.36 (s, br, $1 \mathrm{H}, \mathrm{OH})$. Anal. $\left(\mathrm{C}_{30} \mathrm{H}_{26} \mathrm{~F}_{2} \mathrm{Mg} \mathrm{N} \mathrm{N}_{2} \mathrm{O}_{10} \cdot 2 \mathrm{H}_{2} \mathrm{O}\right) \mathrm{C}, \mathrm{H}, \mathrm{N}$.

Potentiometric Measurements. Materials. The metal ions stock solutions were prepared from $\mathrm{CaCl}_{2} \cdot 6 \mathrm{H}_{2} \mathrm{O}$ (Carlo Erba) and $\mathrm{MnCl}_{2} \cdot 4 \mathrm{H}_{2} \mathrm{O}$ (Janssen), and their concentrations were determined by using EDTA as titrant. The sodium salt of Methylthymol Blue for $\mathrm{Ca}^{2+}$ and Eriochrome Black $\mathrm{T}$ in presence of triethanolamine and hydroxylamine chloride for $\mathrm{Mn}^{2+}$ were used as indicators.

Measurements. Equilibrium constants for protonation and complexation reactions were determined by potentiometric measurements, in methanol/water $=9: 1 \mathrm{v} / \mathrm{v}$ solution at ionic strength of $0.1 \mathrm{M} \mathrm{KCl}$ and $25 \pm 0.1^{\circ} \mathrm{C}$ in the $\mathrm{pH}$ range $2.5-11$ under $\mathrm{N}_{2}$. Temperature was controlled to $\pm 0.1^{\circ} \mathrm{C}$ by using a thermostatic circulating water bath (ISCO GTR 2000 IIx). Appropriate aliquots of ligand solution, prepared by weight, were titrated with standard $\mathrm{KOH}($ methanol/water $=9: 1 \mathrm{v} / \mathrm{v}, I=0.1 \mathrm{M} \mathrm{KCl})$ with and without metal ions. Constant-speed magnetic stirring was applied throughout. Freshly boiled methanol and double distilled water, kept under $\mathrm{N}_{2}$, were used throughout. The experimental procedure for determination of accurate equilibrium constants in this mixed solvent has been described in detail elsewhere. ${ }^{33}$ The protonation constants of the ligands were obtained by titrating $20-50 \mathrm{~mL}$ samples of each ligand $\left(5 \times 10^{-3}-7 \times 10^{-3} \mathrm{M}\right)$. For the complex formation constants, the titrations were performed with different ligand/metal ratios (1 up to 4). At least two measurements (about 60 experimental points in each) were performed for each system. Potentiometric titrations were carried out by a fully automated apparatus equipped with a CRISON GLP 21-22 digital voltmeter (resolution $0.1 \mathrm{mV}$ ) and a $5 \mathrm{~mL}$ Metrohm Dosimat 655 autoburette, both controlled by in-house software, written in BASIC, working on an IBM computer. The electrodic chain (Crison 5250 glass electrode and $\mathrm{KCl} 0.1 \mathrm{M}$ in methanol $/$ water $=9: 1 \mathrm{v} / \mathrm{v}$ calomel electrode, Radiometer 401 ) was calibrated in terms of $\left[\mathrm{H}^{+}\right]$by means of a strong acid-strong base titration, by the Gran's method, ${ }^{34}$ allowing the determination of the standard potential, $E_{\mathrm{o}}(373.7 \pm 0.1 \mathrm{mV})$ and of the ionic product of water, $K_{\mathrm{w}}\left(\mathrm{p} K_{\mathrm{w}}=14.38 \pm 0.01\right)$ in the experimental conditions used. The software HYPERQUAD ${ }^{35}$ was used to evaluate the protonation and complexation constants from EMF data.

X-Ray Crystallography. Single crystal X-ray diffraction analysis of 14 was carried out at room temperature with a computercontrolled Siemens AED diffractometer using $\mathrm{Cu} K \alpha(\lambda=1.54178$ $\AA$ ). No crystal decay was observed. The intensity data were processed with a peak-profile analysis procedure and corrected for Lorentz and polarization effects. The phase problem was solved by direct methods, using SIR 2004. ${ }^{36}$ Full-matrix least-squares refinements were carried out with SHELXS 97, ${ }^{37}$ implemented in the WinGX package. ${ }^{38}$ Anisotropic thermal displacement parameters were refined for all non-H atoms. $\mathrm{H}$ atoms were introduced in calculated positions, riding on their carrier atoms. The positions of hydrogen atoms of $\mathrm{H}_{2} \mathrm{O}$ and $\mathrm{OH}^{-}$were optimized and restrained to make best hydrogen bond contacts to neighboring acceptors. The Cambridge Crystallographic Database software ${ }^{39}$ and PARST $97^{40}$ were used for analyzing and drawing the molecular structure. Data concerning structure solution and refinement are in Table 3.

Biology. Biological Materials, Chemicals, and Enzymes. All compounds were dissolved in DMSO, and the stock solutions were stored at $-20^{\circ} \mathrm{C}$. The $\gamma\left[{ }^{32} \mathrm{P}\right]$-ATP was purchased from PerkinElmer. The expression system for wild-type IN was a generous gift of Dr. Robert Craigie, Laboratory of Molecular Biology, NIDDK, NIH, Bethesda, MD.

Preparation of Oligonucleotide Substrates. The oligonucleotides 21 top, 5'-GTGTGGAAAATCTCTAGCAGT-3' and 21 bot, 5'-ACTGCTAGAGATTTTCCACAC-3' were purchased from Norris Cancer Center Core Facility (University of Southern California) and purified by UV shadowing on polyacrylamide gel. To analyze the extent of $3^{\prime}$-processing and strand transfer using $5^{\prime}$-end labeled substrates, 21top was $5^{\prime}$-end labeled using $\mathrm{T}_{4}$ polynucleotide kinase (Epicenter, Madison, WI) and $\gamma\left[{ }^{32} \mathrm{P}\right]$-ATP (Amersham Biosciences or ICN). The kinase was heat-inactivated and 21 bot was added in 1.5 molar excess. The mixture was heated at $95^{\circ} \mathrm{C}$, allowed to cool slowly to room temperature and run through a spin 25 mini-column (USA Scientific) to separate annealed double-stranded oligonucleotide from unincorporated material.

Integrase Assays. To determine the extent of 3'-processing and strand transfer, wild-type IN was preincubated at a final concentration of $200 \mathrm{nM}$ with the inhibitor in reaction buffer $(50 \mathrm{mM} \mathrm{NaCl}$, $1 \mathrm{mM}$ HEPES, $\mathrm{pH} 7.5,50 \mu \mathrm{M}$ EDTA, $50 \mu \mathrm{M}$ dithiothreitol, $10 \%$ glycerol (w/v), $7.5 \mathrm{mM} \mathrm{MnCl}, 0.1 \mathrm{mg} / \mathrm{mL}$ bovine serum albumin, $10 \mathrm{mM}$ 2-mercaptoethanol, 10\% DMSO, and $25 \mathrm{mM}$ MOPS, $\mathrm{pH}$ 7.2) at $30^{\circ} \mathrm{C}$ for $30 \mathrm{~min}$. Then, $20 \mathrm{nM}$ of the $5^{\prime}$-end ${ }^{32} \mathrm{P}$-labeled linear oligonucleotide substrate was added, and incubation was continued for an additional $1 \mathrm{~h}$. Reactions were quenched by the addition of an equal volume $(16 \mu \mathrm{L})$ of loading dye $(98 \%$ deionized formamide, $10 \mathrm{mM}$ EDTA, $0.025 \%$ xylene cyanol and $0.025 \%$ bromophenol blue). An aliquot ( $5 \mu \mathrm{L})$ was electrophoresed on a denaturing $20 \%$ polyacrylamide gel $(0.09 \mathrm{M}$ tris-borate $\mathrm{pH} 8.3,2$ mM EDTA, 20\% acrylamide, $8 \mathrm{M}$ urea).

Gels were dried, exposed in a PhosphorImager cassette, analyzed using a Typhoon 8610 variable mode imager (Amersham Biosciences), and quantitated using ImageQuant 5.2. Percent inhibition $(\% I)$ was calculated using the following equation:

$$
\% I=100 \times[1-(D-C) /(N-C)]
$$

where $C, N$, and $D$ are the fractions of 21-mer substrate converted to 19 -mer (3'-processing product) or strand transfer products for DNA alone, DNA plus IN, and IN plus drug, respectively. The $\mathrm{IC}_{50}$ values were determined by plotting the logarithm of drug concentration versus percent inhibition to obtain concentration that produced $50 \%$ inhibition.

Molecular Modeling. AutoDock 3.0 ${ }^{41}$ was used as the docking tool, 2D structures of the complexes were derived from ref 1 . The 
free ligand structures were generated by converting smiles to mol2 format using CORINA. ${ }^{42}$ Gasteiger charges and hydrogens were added using Sybyl 7.1. ${ }^{43}$ For the respective complexes, metal ions were added manually in Sybyl 7.1 and placed in a $2 \AA$ distance to the chelating oxygens, and charges of +2.0 were assigned. The bonds belonging to the conjugated system as well as the internal keto-enol hydrogen bond were not allowed to rotate during docking. The modified 1QS4 structure was used as pdb input. ${ }^{44}$ Standard parameters were used for docking, with 50 runs for each experiment and a maximum of 3000000 energy evaluations per run. The grid box was centered at the active site $\mathrm{Mg}^{2+}$ ion coordinates, with the size of $22.5 \AA$ in each direction. The clustering tolerance was set to $1.0 \AA \mathrm{rms}$. Because parameters for the cobalt ion in complexes had not been implemented in AutoDock, the following estimates were used: for the nonbonded 12-6 interaction grid map, parameters were set to $r(\mathrm{Co})=1.30 \AA$ and $\varepsilon(\mathrm{Co})=0.150 \mathrm{kcal} / \mathrm{mol} .^{45}$

Acknowledgment. We thank Dr Maria Orecchioni, Mr Paolo Fiori for assistance with NMR spectroscopy, and Dr Nicolino Pala for its help on the preparation of the ligands. MS is grateful to Fondazione Banco di Sardegna for its partial financial support. The work in NN's laboratory was supported by funds from the Campbell Foundation. The authors thank the "Centro Interfacoltà Misure Giuseppe Casnati" and the "Laboratorio di Strutturistica Mario Nardelli" of the University of Parma for facilities.

Supporting Information Available: Tables S1-S7 derived from docking studies on free ligands and complexes and elemental analysis data for complexes 10-14. This material is free of charge via the Internet at http://pubs.acs.org. Crystallographic data (excluding structure factors) for $\mathbf{1 4}$ have been deposited with the Cambridge Crystallographic Data Centre as supplementary publications nos. CCDC 695468. Copies of the data can be obtained free of charge on application to CCDC, 12 Union Road, Cambridge CB2 1EZ, UK (fax: (+44) 1223-336-033; e-mail: deposit@ccdc.cam.ac.uk).

\section{References}

(1) Sechi, M.; Bacchi, A.; Carcelli, M.; Compari, C.; Duce, E.; Fisicaro, E.; Rogolino, D.; Gates, P.; Derudas, M.; Al-Mawsawi, L. Q.; Neamati, N. From Ligand to Complexes: Inhibition of Human Immunodeficiency Virus Type 1 Integrase by $\beta$-Diketo Acid Metal Complexes. J. Med. Chem. 2006, 49, 4248-4260.

(2) Brown, P. O. Integration. In Retroviruses; Coffin, J. C., Hughes, S. H., Varmus, H. E., Eds.; Cold Spring Harbor Press: Plainview, NY, 1999.

(3) Esposito, D.; Craigie, R. Integrase structure and function. Adv. Virus. Res. 1999, 52, 319-333.

(4) Asante-Appiah, E.; Skalka, A. M. A molecular mechanisms in retrovirus DNA integration. Antiviral Res. 1997, 36, 139.

(5) Neamati, N. Structure-based HIV-1 integrase inhibitor design: a future perspective. Expert Opin. Investig. Drugs 2001, 10, 281-96.

(6) Anthony, N. J. HIV-1 integrase: a target for new AIDS chemotherapeutics. Curr. Top. Med. Chem. 2004, 4, 979-90.

(7) Pommier, Y.; Johnson, A. A.; Marchand, C. Integrase inhibitors to treat HIV/AIDS. Nat. Rev. Drug. Discovery 2005, 4, 236-48.

(8) Engelman, A.; Bushman, F. D.; Craigie, R. Identification of discrete functional domains of HIV-1 integrase and their organization within an active multimeric complex. EMBO J. 1993, 12, 3269-3275.

(9) Engelman, A.; Mizuuchi, K.; Craigie, R. HIV-1 DNA integration: mechanism of viral DNA cleavage and DNA strand transfer. Cell 1991, 67, 1211-1221.

(10) Asante-Appiah, E.; Skalka, A. M. HIV-1 integrase: structural organization, conformational changes, and catalysis. Adv. Virus Res. 1999, 52, 351-69.

(11) Chiu, T. K.; Davies, D. R. Structure and function of HIV-1 integrase. Curr. Top. Med. Chem. 2004, 4, 965-77.

(12) Dayam, R.; Neamati, N. Small-molecule HIV-1 integrase inhibitors: the 2001-2002 update. Curr. Pharm. Des. 2003, 9, 1789-802.

(13) Dayam, R.; Deng, J.; Neamati, N. HIV-1 integrase inhibitors: 20032004 update. Med. Res. Rev. 2006, 26, 271-309.

(14) Dayam, R.; Gundla, R.; Al-Mawsawi, L. Q.; Neamati, N. HIV-1 integrase inhibitors: 2005-2006 update. Med. Res. Rev. 2008, 28, 118154.

(15) Cotelle, P. Patented HIV-1 integrase inhibitors (1998-2005). Recent Patents Anti-Infect. Drug Discovery 2006, 1, 1-15.
(16) Johnson, A. A.; Marchand, C.; Pommier, Y. HIV-1 integrase inhibitors: a decade of research and two drugs in clinical trial. Curr. Top. Med. Chem. 2004, 4, 671-86.

(17) Zeinalipour-Loizidou, E.; Nicolaou, C.; Nicolaides, A.; Kostrikis, L. G. HIV-1 Integrase: From Biology to Chemotherapeutics. Curr. HIV Res. 2007, 5, 365-88.

(18) Hazuda, D. J.; Felock, P.; Witmer, M.; Wolfe, A.; Stillmock, K.; Grobler, J. A.; Espeseth, A.; Gabryelski, L.; Schleif, W.; Blau, C.; Miller, M. D. Inhibitors of strand transfer that prevent integration and inhibit HIV-1 replication in cells. Science 2000, 287, 646-50.

(19) Goldgur, Y.; Craigie, R.; Cohen, G. H.; Fujiwara, T.; Yoshinaga, T.; Fujishita, T.; Sugimoto, H.; Endo, T.; Murai, H.; Davies, D. R. Structure of the HIV-1 integrase catalytic domain complexed with an inhibitor: a platform for antiviral drug design. Proc. Natl. Acad. Sci. U.S.A. 1999, 96, 13040-13043.

(20) Pais, G. C. G.; Burke, T. R. Novel aryl diketo-containing inhibitors of HIV-1 integrase. Drugs Future 2002, 27, 1101-1111.

(21) Wang, Y.; Serradell, N.; Bolos, J.; Rosa, E. MK-0518, HIV integrase inhibitor. Drugs Future 2007, 32, 118-122.

(22) Rowley, M. The Discovery of Raltegravir, An Integrase Inhibitor for the Treatment of HIV Infection. Prog. Med. Chem. 2008, 46, 1-28.

(23) Grinsztein, B.; Nguyen, B.-Y.; Katlama, C.; Gatell, J. M.; Lazzarin, A.; Vittecoq, V.; Gonzalez, C. J.; Chen, J.; Harvey, C. M.; Isaacs, R. D. Safety and efficacy of the HIV-1 integrase inhibitor raltegravir (MK-0518) in treatment-experienced patients with multidrug-resistant virus: a phase II randomised controlled trial. Lancet 2007, 369, 12611269.

(24) Sorbera, L. A.; Serradell, N. GS-9137. Anti-HIV agent, HIV integrase inhibitor. Drugs Future 2006, 31, 310-313.

(25) Sato, M.; Motomura, T.; Aramaki, H.; Matsuda, T.; Yamashita, M.; Ito, Y.; Kawakami, H.; Matsuzaki, Y.; Watanabe, W.; Yamataka, K.; Ikeda, S.; Kodama, E.; Matsuoka, M.; Shinkai, H. Novel HIV-1 Integrase Inhibitors Derived from Quinolone Antibiotics. J. Med. Chem. 2006, 49, 1506-1508.

(26) Grobler, J. A.; Stillmock, K.; Hu, B.; Witmer, M.; Felock, P.; Espeseth, A. S.; Wolfe, A.; Egbertson, M.; Bourgeois, M.; Melamed, J.; Wai, J. S.; Young, S.; Vacca, J.; Hazuda, D. J. Diketo acid inhibitor mechanism and HIV-1 integrase: implications for metal binding in the active site of phosphotransferase enzymes. Proc. Natl. Acad. Sci. U.S.A. 2002, 99, 6661-6666.

(27) Sechi, M.; Carcelli, M.; Rogolino, D.; Neamati, N. Role of metals in HIV-1 integrase inhibitor design. In: HIV-1 Integrase: Mechanism of Action and Inhibitor Design; John Wiley \& Sons: New York, in press.

(28) Espeseth, A. S.; Felock, P.; Wolfe, A.; Witmer, M.; Grobler, J.; Anthony, N.; Egbertson, M.; Melamed, J. Y.; Young, S.; Hamill, T.; Cole, J. L.; Hazuda, D. J. HIV-1 integrase inhibitors that compete with the target DNA substrate define a unique strand transfer conformation for integrase. Proc. Natl. Acad. Sci. U.S.A. 2000, 97, 11244-11249.

(29) Kawai, H.; Kitano, Y.; Mutoh, M.; Hata, G. Synthesis, structure and antitumor activity of a new water-soluble platinum complex, $(1 R, 2 R-$ cyclohexanediamine- $N, N^{\prime}$ )[2-hydroxy-4-oxo-2-pentenoato(2-)$\mathrm{O}_{2}$ platinum(II). Chem. Pharm. Bull. (Tokyo) 1993, 41, 357-361.

(30) Landry, B. R.; Turnbull, M. M.; Twamley, B. Synthesis and structure of a novel copper(II) nitrate complex of 2,4-dioxo-4-phenylbutanoic acid. J. Chem. Crystallogr. 2007, 37, 81-86.

(31) Jaskolski, M.; Alexandratos, J. N.; Bujacz, G.; Wlodawer, A. Structural studies of retroviral integrases. In: HIV-1 Integrase: Mechanism of Action and Inhibitor Design; John Wiley \& Sons: New York, in press.

(32) Lins, R. D.; Straatsma, T. P.; Briggs, J. M. Similarities in the HIV-1 and ASV Integrase Active Sites Upon Metal Cofactor Binding. Biopolymers 2000, 53, 308-315.

(33) Fisicaro, E.; Braibanti, A. Potentiometric titrations in methanol/water medium: Intertitration variability. Talanta 1988, 35, 769-774.

(34) Gran, G. Determination of the equivalence point in potentiometric titrations. Part II. Analyst 1952, 77, 661.

(35) Gans, P.; Sabatini, A.; Vacca, A. Investigation of equilibria in solution. Determination of equilibrium constants with the HYPERQUAD suite of programs. Talanta 1996, 43, 1739-1753.

(36) Burla, M. C.; Camalli, M.; Carrozzini, B.; Cascarano, G. L.; Giacovazzo, C.; Polidori, G.; Spagna, R. SIR2002: the program. J. Appl. Crystallogr. 2003, 36, 1103.

(37) Sheldrick G. M. SHELXL97. Program for the Refinement of Crystal Structures; University of Gottingen: Gottingen, Germany, 1997.

(38) Farrugia, L. J. Win GX suite for small-molecule single-crystal crystallography. J. Appl. Crystallogr. 1999, 32, 837-838.

(39) Bruno, I. J.; Cole, J. C.; Edgington, P. R.; Kessler, M.; Macrae, C. F.; McCabe, P.; Pearson, J.; Taylor, R. New software for searching the Cambridge Structural Database and visualizing crystal structures. Acta Crystallogr., Sect. B: Struct. Sci. 2002, 58, 389-397.

(40) Nardelli, M. PARST95-an update to PARST: a system of Fortran routines for calculating molecular structure parameters from the results of crystal structure analyses. J. Appl. Crystallogr. 1995, 28, 659. 
(41) Morris, G. M.; Goodsell, D. S.; Halliday, R. S.; Huey, R.; Hart, W. E.; Belew, R. K.; Olson, A. J. Automated docking using a Lamarckian genetic algorithm and an empirical binding free energy function. J. Comput. Chem. 1998, 19, 1639-1662.

(42) CORINA, Molecular Networks GmbH Computerchemie, Nägelsbachstr. 25, 91052 Erlangen, Germany.

(43) SYBYL 7.1, Tripos International, 1699 South Hanley Rd., St. Louis, Missouri 63144, USA.
(44) Sotriffer, C. A.; Ni, H.; McCammon, J. A. Active site binding modes of HIV-1 integrase inhibitors. J. Med. Chem. 2000, 43, 4109-4117.

(45) Marques, H. M.; Ngoma, B.; Egan, T. J.; Brown, K. L. Parameters for the AMBER force field for the molecular mechanics modeling of the cobalt corrinoids. J. Mol. Struct. 2001, 561, 71-91.

JM800893Q 